\title{
Bank Branching Deregulation and the Syndicated Loan Market
}

\author{
Jan Keil and Karsten Müller*
}

\begin{abstract}
How do changes in banking regulation affect the syndicated loan market? Because branch networks and loan syndication both enable banks to diversify geographical credit risk, we investigate the staggered implementation of the Riegle-Neal Interstate Branching and Banking Efficiency Act of 1994. Exploiting that the act only changed the legal framework for out-of-state commercial banks, we find that branching deregulation decreased syndicated loan issuance but spurred bilateral lending to corporations. Consistent with a supply-driven substitution effect, this shift is also reflected in interest rate spreads. Our results suggest that changes to banking regulation can substantially alter credit allocation across loan types.
\end{abstract}

\section{Introduction}

The market for syndicated loans is the most important source of corporate financing in the United States. ${ }^{1}$ As a result, syndicated loans have been at the center of a large and active body of research. ${ }^{2}$ However, there is surprisingly little

*Keil (corresponding author), jan.keil@hu-berlin.de, Humboldt University of Berlin School of Business and Economics; Müller, karstenm@princeton.edu, Princeton University. We are extremely grateful to Matthieu Chavaz, Stuart Fraser, Rustom Irani, Randy Kroszner, Frédéric Malherbe, James Mitchell, Steven Ongena, Philip Strahan, Michael Weber, and an anonymous referee for helpful discussions and comments. We also thank seminar and conference participants at the University of Chicago, Warwick University, DeFaul University, and Oxford University for their helpful feedback. Müller was supported by a Doctoral Training Centre scholarship granted by the Economic and Social Research Council (grant 1500313).

${ }^{1}$ With USD 2 trillion in annual issuance, it accounts for a larger volume than corporate bonds issued by domestic companies; half of all commercial and industrial (C\&I) loans in the United States are underwritten by a syndicate (see https://www.bloomberg.com/professional/blog/globalsyndicated-loans-league-tables-fy-2016/, https://www.federalreserve.gov/releases/e2/current/default .htm, and Ivashina (2009), Lee, Liu, and Stebunovs (2017)).

${ }^{2}$ For important contributions on syndicated loans see, among others, Sufi (2007), Ivashina (2009), Ivashina and Scharfstein (2010), Gopalan, Nanda, and Yerramilli (2011), Lin, Ma, Malatesta, and Xuan (2012), Ferreira and Matos (2012), Lim, Minton, and Weisbach (2014), Chodorow-Reich (2014), Berg, Saunders, and Steffen (2016), Amiram, Beaver, Landsman, and Zhao (2017), and Cai, Saunders, and Steffen (2017). Many other authors have used syndicated loan market data as the primary source in their analyses (e.g., De Haas and Van Horen (2012), Axelson, Jenkinson, Strömberg, 
evidence on how the sweeping changes to banking regulations over the past decades have affected the market. In this article, we take one step toward closing this gap and investigate the impact of the Riegle-Neal Interstate Banking and Branching Efficiency Act of 1994 (IBBEA) on the pricing and issuance of syndicated loans.

Syndicated loan contracts are originated, structured, and managed by lead banks, which usually screen and monitor borrowers. Apart from collecting fees, one of the primary motivations for lead banks to syndicate loans is to diversify credit risk (Simons (1993), Preece and Mullineaux (1996), and Gadanecz (2004)). Syndication, however, comes at a cost: Coordination among multiple creditors is fraught with asymmetric information and moral-hazard problems (Pennacchi (1988), Gorton and Pennacchi (1995), Ivashina (2009), and Sufi (2007)) and becomes particularly complex during renegotiations (Gertner and Scharfstein (1991), Preece and Mullineaux (1996), and Bris and Welch (2005)). As a result, lenders face a trade-off between the advantage of risk diversification and higher coordination costs vis-à-vis other syndicate members. An alternative for a lead bank to diversify its loan portfolio is to rely on direct lending via a branching network (Demsetz (2000), Deng and Elyasiani (2008), and Goetz, Laeven, and Levine (2013), (2016)).

The IBBEA lifted restrictions on commercial banks to permit them to branch freely across state borders and thus facilitated geographical diversification by allowing more direct access to borrowers (Hughes, Lang, Mester, and Moon (1996), Demsetz (2000), Calomiris (2000), and Akhigbe and Whyte (2003)). The effect on banking markets was transformative. Out-of-state banks formed extensive, consolidated branching networks, which increased their market share from only $2.5 \%$ in 1994 to $45.8 \%$ in 2011. Research on lender-borrower distance suggests that the resulting reduction of physical proximity enabled banks to screen and monitor borrowers more effectively (Petersen and Rajan (2002), Degryse and Ongena (2005), Hauswald and Marquez (2006), Hollander and Verriest (2016), and D'Acunto, Liu, Pflueger, and Weber (2017)) and without the coordination costs from syndication. We hypothesize that the IBBEA thus changed the incentives of commercial banks to originate syndicated compared with bilateral loans to diversify credit risk.

Consistent with this intuition, we find that the issuance of syndicated loans decreased at both the bank and state levels after branching deregulation, whereas bilateral lending increased. The overall lending impact of the IBBEA appears to have been positive, albeit small in percentage terms, consistent with Rice and Strahan (2010). Our results thus point to a shifting of debt contract types from syndicated to bilateral loans. We also show that the effects of the IBBEA at the state level crucially depend on banking-sector concentration prior to the reform (see also Black and Strahan (2002), Cetorelli and Strahan (2006)). States with little competition before deregulation, where branching networks expanded

and Weisbach (2013), Dougal, Engelberg, Parsons, and Van Wesep (2015), Ivashina, Scharfstein, and Stein (2015), Kalemli-Ozcan, Kamil, and Villegas-Sanchez (2016), Falato and Liang (2016), Saidi and Neuhann (2018), and Müller (2019). 
most after the restrictions were lifted, saw the largest effect for both direct and syndicated lending.

To refine our identification strategy, we exploit cross-sectional variation in loan characteristics. The resulting triple-difference setup generates loan-level variation, which allows us to absorb unobserved time-varying borrower and bank characteristics using borrower $\times$ year and bank $\times$ year fixed effects. Because borrowers frequently issue multiple individual facilities in the same year $(40 \%$ in our estimation sample), the data give us ample variation. The benefit of this approach is that we can rule out alternative explanations based on unobserved borrower risk or credit demand.

We find that the IBBEA had a differential effect on debt pricing: Interest rate spreads for bilateral loans decreased by approximately $7 \%$ but increased for syndicated loans by approximately $2 \%$. Although direct loans are more expensive throughout (see also Angbazo, Mei, and Saunders (1998), Dennis and Mullineaux (2000), and Ivashina (2005)), they are less so after branching deregulation. Interpreted jointly with the effect on lending volumes, these results suggest that access to credit improved at the expense of syndicated lending following interstate branching deregulation. Exploring heterogeneity in borrower attributes, we also find that smaller, riskier, and more opaque firms experienced a decrease in interest rates. This is consistent with branches lowering monitoring costs by decreasing the distance between lenders and borrowers (D'Acunto et al. (2017)).

Syndicated loans, however, also differ from bilateral contracts in other aspects: they tend to be considerably larger and carry longer maturities, even after controlling for borrower fundamentals. To rule out alternative explanations, we make use of the fact that only one group of lead arrangers was subject to the reform: out-of-state commercial banks. The regulatory change did not alter the legal framework for other lenders, such as pension funds, hedge funds, investment banks, or commercial banks with headquarters within a deregulating state (Johnson and Rice (2008), Favara and Imbs (2015)). ${ }^{3}$ Importantly, the loans issued by out-of-state commercial banks are not systematically different from those issued by nonbank lenders or in-state banks. Consistent with our substitution hypothesis, we find that only affected lenders saw increased spreads, even within the same borrower-year; other loans carried lower interest rates after deregulation, consistent with an increase in lending competition.

We propose a set of tests to support the validity of our empirical approach. We find that interest rate spreads and loan volumes exhibit a level shift around the state-level implementation of the IBBEA without preexisting trends or reversals. Further, we construct a placebo test and find that the sequence of the staggered deregulation is not correlated with changes in spreads before the reform. We also provide some evidence that the reform timing is not driven by a state's syndicated loan market size or its market concentration. Our results are also robust to a host of 98 validity checks that let us rule out sample-selection concerns, the influence

\footnotetext{
${ }^{3}$ Thrift and other deposit-taking and non-deposit-taking organizations were able to engage in interstate branching before the IBBEA (Rice and Strahan (2010)). See also http://www.pli.edu/ product_files/Titles\%2F4655\%2F55199_sample02_20141011115534.pdf for a discussion of how branching regulations affected different financial institutions.
} 
of single states, joint determination in loan terms, and the tranching of facilities for nonbank investors.

We build on the insight that banks are relevant even for large, publicly listed companies with direct access to financial markets (e.g., Dahiya, Saunders, and Srinivasan (2003), Bharath, Dahiya, Saunders, and Srinivasan (2007), Ross (2010), Chodorow-Reich (2014), and Cai et al. (2017)). For example, lending relationships in the syndicated loan market have been found to affect interest rates spreads (Schenone (2010), Bharath, Dahiya, Saunders, and Srinivasan (2011)), loan terms during financial distress ( $\mathrm{Li}, \mathrm{Lu}$, and Srinivasan (2019)), corporate governance (Dass and Massa (2011)), and firm outcomes (Gopalan, Udell, and Yerramilli (2011)). More broadly, Sufi (2007) finds that proxies for information asymmetries shape monitoring incentives. In a recent article, D'Acunto et al. (2017) show that the leverage of publicly listed firms increased with branching deregulation, which the authors interpret as a shock to monitoring costs. This literature suggests that the sweeping changes to the U.S. banking system brought about by the IBBEA may also affect the syndicated loan market.

Our work further contributes to the literature on the influence of geographical diversification for bank risk (Diamond (1984), Demsetz and Strahan (1997), Acharya, Hasan, and Saunders (2006), and Goetz et al. (2013), (2016)), physical distance for loan terms and access to credit (Petersen and Rajan (2002), Degryse and Ongena (2005), Hauswald and Marquez (2006), and Hollander and Verriest (2016)), and the effects of U.S. branching deregulation (e.g., Stiroh and Strahan (2003), Johnson and Rice (2008), Rice and Strahan (2010), Chava, Oettl, Subramanian, and Subramanian (2013), and Jiang, Levine, and Lin (2017)). More broadly, our work is embedded in the literature on financial deregulation in the United States. ${ }^{4}$ Banking deregulation has been associated with higher per capita growth rates (Jayaratne and Strahan (1996)), higher loan volumes (Amore, Schneider, and Zaldokas (2013)), lower income inequality (Beck, Levine, and Levkov (2010)), and many other economic outcomes. Our article is also related to studies investigating the reallocation effects of financial reforms, such as those of Chava et al. (2013) and Hombert and Matray (2016), who show that intrastate branching deregulation decreased innovation by firms with fewer pledgeable assets. $^{5}$

The remainder of the article is organized as follows: In Section II, we discuss why lenders might use syndication to geographically diversify their loan portfolios and how this relates to branching restrictions. Section III presents the data and variable construction. Section IV introduces the identification strategy and discusses the results. Section V concludes.

\section{Hypothesis Development}

The hypothesis we are testing in this article is that allowing interstate branching decreased the benefits of loan syndication for the out-of-state commercial banks affected by the IBBEA. To explain the underlying rationale, we review the

\footnotetext{
${ }^{4}$ See, for example, Kroszner and Strahan (2014) for an excellent review of the topic.

${ }^{5}$ See also Boot and Thakor (2000) for evidence on the reallocation effects of increases in competition.
} 
institutional details of the IBBEA and discuss how it may have affected the profitability of lead banks engaging in loan syndication. A comprehensive discussion of loan syndication is beyond the scope of this article; we focus instead on the mechanisms that were likely influenced by the existence of geographical restrictions and their deregulation. ${ }^{6}$

\section{A. Riegle-Neal Interstate Banking and Branching Efficiency Act of 1994}

Congress introduced the IBBEA of 1994 with the intention of removing restrictions on interstate branching (i.e., allowing banks to open branches outside their home states and operate these directly within the central organization of the bank holding company (BHC)). Interstate branching differs from interstate banking, where a BHC founds or acquires institutions in other states to operate them as separately chartered and capitalized subsidiaries. Most restrictions to this latter form of expansion as well as other geographical limitations within states were lifted several years before the IBBEA (Berger, Kashyap, Scalise, Gertler, and Friedman (1995), Jayaratne and Strahan (1998), and Johnson and Rice (2008)). ${ }^{7}$ In contrast, interstate branching restrictions were almost uniformly in place in 1994, when only Utah allowed unrestricted and unconditional interstate branching. ${ }^{8}$ While facilitating the transition toward a liberalized system, the IBBEA allowed individual states to effectively impose anticompetitive obstacles to interstate branching. First, states were allowed to set minimum age requirements (up to 5 years) with respect to how long a bank must have been in existence before being acquired in an interstate merger. This also forced banks to wait until newly established subsidiary offices could be consolidated to branches. Second, the IBBEA preserved the right of states to impose deposit caps of less than $30 \%$. This served to prevent interstate mergers that would result in banks accounting for a greater share in insured state deposits than set by the cap (including deposits of affiliated institutions). In essence, this protected large state banks from takeovers. Third, an initial entry by a bank through de novo interstate branching was only permitted if states "opted in" to allow this explicitly. Fourth, states had to opt in to legalize the acquisition of a single branch or a number of branches (without acquiring the entire bank itself). Any of these four provisions could be offered by states with reciprocity.

All these possible restrictions limited the available paths of entry, slowed down the process, and added significant costs for banks to enter other states' markets. Further, individual states lifted these restrictions at different points of time

\footnotetext{
${ }^{6}$ Other important motives omitted in the discussion are that syndication allows lead arrangers to specialize in certain types of lending (Gorton and Pennacchi (1995)) and increase their fee-based income (Dennis and Mullineaux (2000)).

${ }^{7}$ All states except Hawaii had entered an interstate banking agreement by 1994, whereas failed large banks and thrifts or those at risk of failing could be acquired by out-of-state banks nationwide, irrespective of state laws, since 1982. Intrastate branching was deregulated in all states but one in 1994, and all states relaxed intrastate banking restrictions before 1992 (Jayaratne and Strahan (1998), Kroszner and Strahan (1999), (2014)).

${ }^{8}$ Nevada allowed interstate branching for counties with a population of less than 100,000 , and six other states allowed some form of interstate branching on a reciprocal basis. Prior to the IBBEA, nationally chartered banks in locations close to a state border could also move their main office to a different state, leaving the former location as a branch (Johnson and Rice (2008)).
} 


\section{FIGURE 1}

Market Share of Out-of-State Banks, 1994 versus 2011

Figure 1 plots the market share of out-of-state banks (those with an ultimate holding company located in another state) based on deposits in 1994 and 2011. The state-level market shares are the deposit-weighted averages based on countylevel data from the Federal Deposit Insurance Corporation (FDIC).

\section{Graph A. 1994}
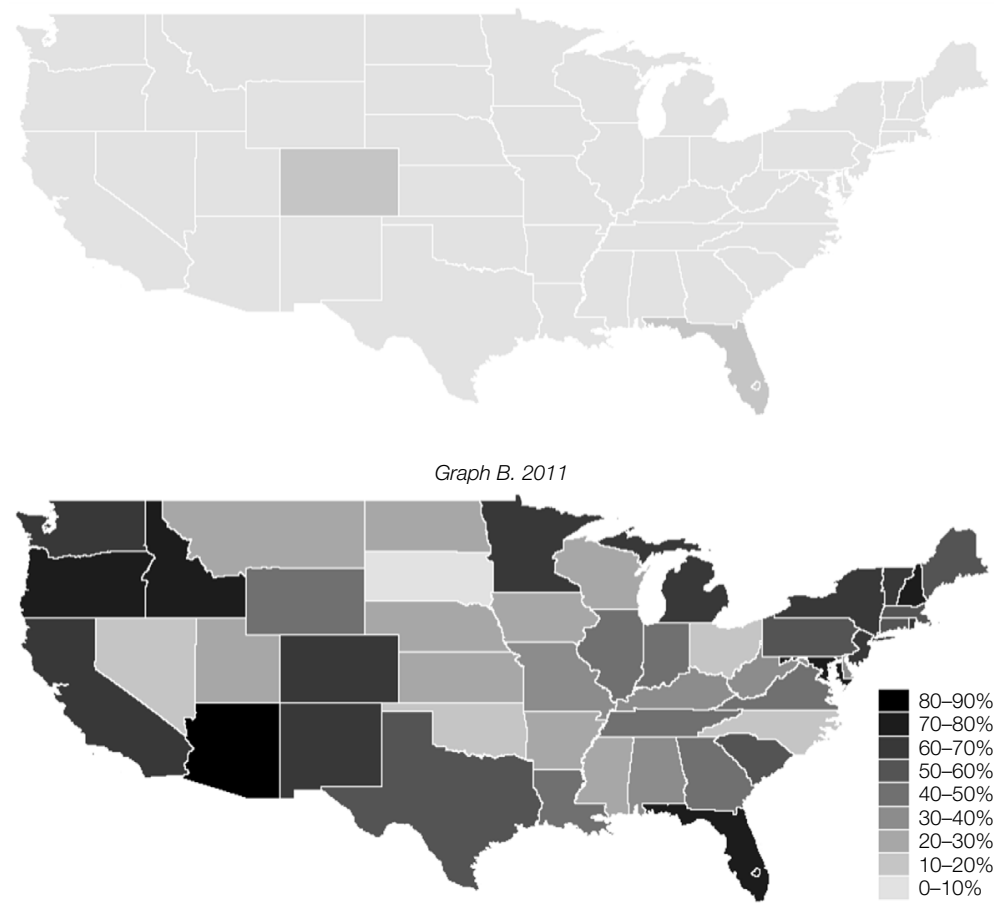

and to varying degrees (Johnson and Rice (2008)), a fact we exploit in our identification strategy. The massive effect on local banking industries is illustrated in Figure 1: The average deposit market share of out-of-state banks increased from only $2.5 \%$ in 1994 to $45.8 \%$ in 2011 .

\section{B. Syndicated versus Bilateral Loans}

Syndicated loans are partial substitutes for direct bilateral lending through bank branches (Demsetz (2000)). Syndication has several advantages but also incurs coordination costs because of adverse selection and moral-hazard problems, arising from lead banks' incentive to syndicate risky loans and cut down on monitoring effort (Pennacchi (1988), Gorton and Pennacchi (1995), Holmstrom and Tirole (1997), Sufi (2007), and Ivashina (2009)). The complexity and cost of renegotiations are also higher for syndicated contracts with multiple creditors and different claims or interests vis-à-vis a borrower than for bilateral loans (Gertner and Scharfstein (1991), Preece and Mullineaux (1996), 
and Bris and Welch (2005)). ${ }^{9}$ Accordingly, lenders must balance these syndicatespecific coordination costs with the benefits of syndication.

Direct lending via a bank's own branching networks is not associated with creditor coordination costs (Demsetz (2000)) but involves screening and monitoring expenses. In a syndicate, these costs are shared with participants (which usually pay fees to the lead arranger) and are likely to be lower because syndicate leaders prefer to minimize their screening and monitoring efforts. Because the costs of screening and monitoring increase with physical lender-borrower distance (Petersen and Rajan (2002), Degryse and Ongena (2005), Hauswald and Marquez (2006), Hollander and Verriest (2016)), the creation of branches in distant states can be interpreted as a negative shock to these costs (D'Acunto et al. (2017)). This likely increased the profitability of bilateral relative to syndicated loans.

Risk diversification is one of the main reasons commercial banks syndicate loans (Simons (1993), Preece and Mullineaux (1996), and Sufi (2007)). Lead banks can share loan exposure with other lenders, which may reduce exposure to idiosyncratic local shocks and enhance stability (Diamond (1984), Boyd and Prescott (1986), Demsetz and Strahan (1997), and Berger, Demsetz, and Strahan (1999)). ${ }^{10}$ In a regulatory regime that inhibits (direct) geographical diversification and closely ties the fortunes of banks to their local economies (Calomiris (2006)), syndication helps overcome limitations and reduces exposure to geographical and local industry shocks (Simons (1993), Dennis and Mullineaux (2000), and Gadanecz (2004)). Others have argued that direct lending via a broad branching network is an alternative way to diversify a loan portfolio (Demsetz (2000), Deng and Elyasiani (2008), and Goetz et al. (2013), (2016)) and that banks took advantage of this newly available alternative following the IBBEA (Hughes et al. (1996), Calomiris (2000), and Akhigbe and Whyte (2003)).

Loan syndication is also a way for lead banks to reduce "concentration risk" and meet related regulatory rules (Berger and Udell (1993), Simons (1993), Dennis and Mullineaux (2000), and Gadanecz (2004)). For example, the Federal Deposit Insurance Corporation (FDIC) requires banks to limit the loan size to a single borrower to $15 \%$ of its capital and reserves (25\% if fully secured by readily marketable collateral). ${ }^{11}$ To comply with regulatory requirements and reduce exposure to large individual borrowers, lead banks may prefer to share credit risk exposures with other lenders instead of holding them entirely on their own balance sheet (Pennacchi (1988), Dennis and Mullineaux (2000), and Simons (1993)). Syndicated lending especially allows smaller banks to lend to large borrowers they could not otherwise serve without "overlining" regulatory limits. Large borrowers, however, have considerably lower default rates and more "prestige" from which banks may benefit (Muermann, Rauter, and Scheuch (2017)). The dramatic

\footnotetext{
${ }^{9} \mathrm{~A}$ recent example of an analysis of creditor coordination costs in the context of covenant-light contracts is Becker and Ivashina (2016). Hart and Moore (1995), Bolton and Scharfstein (1996), and Bris, Welch, and Zhu (2006) focus on creditor coordination more broadly.

${ }^{10}$ In line with this, Deng and Elyasiani (2008) find a premium for U.S. banks diversifying nationally, and Goetz et al. (2013, 2016) find that geographic expansion reduces bank risk.

${ }^{11}$ See https://www.fdic.gov/regulations/laws/rules/8000-7400.html. Syndication can also help meet minimum capital requirements (Simons (1993)).
} 
increase in bank size following interstate branching deregulation (median deposits were \$74 million in 1994 and \$137 million in 2011 in real terms) likely eroded this advantage of syndication by allowing the typical bank to underwrite considerably larger (bilateral) loans entirely on its own. ${ }^{12}$

Access to large or distant borrowers through syndication further enables lenders to cross-sell other services (Gadanecz (2004)). The revenue from these sales might have cross-subsidized spreads on syndicated loans prior to deregulation (Gaspar, Massimo, and Matos (2006), Lepetit, Nys, Rous, and Tarazi (2008)), which may partially explain the discount compared to bilateral loans (Angbazo et al. (1998), Dennis and Mullineaux (2000), and Ivashina (2005)). The newly gained ability to directly access potential customers after deregulation may reduce the willingness to continue offering the previously "subsidized" rates on syndicated loans.

Overall, it appears reasonable to expect that more extensive branching networks post-deregulation induced banks to partially substitute syndicated for bilateral loans. Empirically, we would expect less syndicated loan issuance, a larger supply of bilateral loans, and a lower interest rate discount for syndicated loans. In particular, one would expect a decrease in the spreads of bilateral contracts, consistent with an increase in credit supply (and previous evidence in Rice and Strahan (2010) and D'Acunto et al. (2017)). The impact of IBBEA implementation should also be entirely driven by the lenders that were legally affected by the IBBEA, namely, out-of-state commercial banks (Johnson and Rice (2008), Favara and Imbs (2015)). We put these empirical predictions to the test in Section IV.

\section{Data}

\section{A. Data Sources}

The main data sources are detailed loan information from the Thomson Reuters LPC DealScan database matched with firm-level data from the Standard \& Poor's (S\&P) Compustat North American Annual Fundamentals file. We use the Compustat Ratings package and Mergent's Fixed Income Securities Database (FISD) to obtain information on firm ratings. As is standard in the literature, we exclude financial firms (Standard Industrial Classification (SIC) 6000-6999), regulated utilities (SIC 4900-4999), and public administration (SIC > 9000). We also drop all non-U.S. firms and firm-years with negative assets.

We matched the DealScan files to the firm-level data using the DealScanCompustat link file from Chava and Roberts (2008). We start our estimation sample in 1987 to establish a reasonable pre-reform control group before the passage of the IBBEA in 1994. In our main estimations, we restrict the sample to the period up to and including 2007 to abstract from the impact of the financial crisis, which may have had a differential impact across states depending on their

\footnotetext{
${ }^{12}$ In an interview with the Frankfurter Allgemeine Zeitung in 2008, the chief executive officer (CEO) of Commerzbank explained the rationale as follows: "If a multinational corporation requested a $€ 10$ billion loan for an acquisition in the past, you would have to form a syndicate for that. Today, a single large bank can lend such an amount and keep the entire profit for itself" (http://www.faz.net/aktuell/wirtschaft/unternehmen/commerzbank-chef-mueller-im-interviewwir-haben-uns-in-der-krise-gut-behauptet-1548096-p2.html).
} 
liberalization policies. We show in Section IV.F that our results are robust to extending the sample period until 2012 (the end of the Chava-Roberts link file).

We capture the intensity of branching deregulation using the time-varying index of Rice and Strahan (2010). They set the index to 0 for states with no restrictions and add 1 for each type of restriction imposed, with the index ranging from 0 to $4 .^{13}$ The index is matched to our DealScan-Compustat data set using Compustat's location data (variable state) and the exact date branch restrictions were lifted. ${ }^{14}$ We use this variation to create a dummy variable if a state lifted at least one restriction, as in D'Acunto et al. (2017), Chava et al. (2013), and Koetter, Kolari, and Spierdijk (2012). The resulting "treatment" dummy is 1 for all state-years in which the index is equal to 1 or larger, and 0 otherwise, indicating that out-of-state state banks are allowed to erect or acquire local branches. We later show that our results are robust to using the (reversed) continuous index from Rice and Strahan (2010).

We use data from the FDIC's Summary of Deposits to measure a state's existing market concentration prior to the passage of the IBBEA in $1994 .{ }^{15}$ More specifically, we calculate a county's Herfindahl-Hirschman index (HHI) based on the deposits held by each bank and then aggregate this to the state level by weighting by a county's total deposits. We also draw on FDIC data to identify whether a bank had a branch presence in a state prior to deregulation. These data are only available from 1994.

\section{B. Variable Construction}

The unit of observation in the first part of our study is a loan contract facility, where multiple facilities may be included in a deal package. The main dependent variable is a loan's all-drawn interest rate spread (usually over the London Interbank Offered Rate (LIBOR)).

To isolate the effect of branching deregulation on spreads, we hold the contract term loan size and maturity (in natural logarithms) constant in the baseline regressions and include a dummy for whether a loan uses collateral. All regressions include dummy variables for whether a firm has ever received a loan from the lead arranger bank to control for an existing lender-borrower relationship, as well as for whether a facility is a term loan. We also control for differences across loan purposes by including a full set of 22 dummy variables. ${ }^{16}$

\footnotetext{
${ }^{13}$ Following Rice and Strahan (2010) and Favara and Imbs (2015), we set the index to "fully restricted" (0) before 1994 where we have no further information, assuming that states were fully restricted before the passage of the IBBEA. This is a reasonable approximation given the evidence on limited de facto cross-border branching activity presented earlier. Note that although the original index ends in 2005, we let it run until 2007 as in D'Acunto et al. (2017) because no state reversed its liberalization decision.

${ }^{14}$ For each facility, we know the exact issuance date and use this to merge loans with deregulation dates. All results presented here are robust to assigning the index based on the year of implementation. These results are available from the authors.

${ }^{15}$ Alaska is the only state that lifted a branching restriction in the year of the reform in 1994 .

${ }^{16}$ Because we are interested in loans used for normal business transactions, we exclude all loans whose primary purpose is related to merger and acquisition activities. Such loans are identified as "Acquis. line," "LBO," "MBO," "Merger," "SBO," or "Takeover." This exclusion, however, does not drive our results.
} 
In our triple-difference estimations, we use cross-sectional exposure at the facility level. First, we look at syndicated loans, which we define as facilities with a distribution method other than "sole lender." Second, we use a dummy equal to 1 when the lender is a commercial bank (identified as lenders with an SIC 3-digit code of 602). For both exposure variables, an average of approximately $79 \%$ of loans in the estimated sample are considered "treated." ${ }^{17}$ We also condition the reform impact on whether a bank had a branch presence in the borrower state prior to IBBEA implementation ("out-of-state bank"). The focus on branches is motivated by the IBBEA institutional detail, as banks were allowed to operate local non-consolidated subsidiaries, which in turn may have had branches, even before IBBEA implementation. Most lead arrangers in the sample, around 62\%, did not have a local presence prior to the reform.

We also control for borrower fundamentals from Compustat, including book leverage, Tobin's Q, total assets (in natural logarithm), sales growth, return on assets (ROA), an indicator for rated firms, and quartiles for borrowers with negative or very high ratios of debt to earnings before interest, taxes, depreciation, and amortization (EBITDA) (Roberts and Sufi (2009), Nini, Smith, and Sufi (2009)). The exact variable definitions can be found in the Supplementary Material, and the summary statistics are given in Table 1 . To minimize the impact of outliers, we exclude firm-years with total asset growth exceeding $200 \%$ and winsorize balancesheet variables at the 1st and 99th percentiles; Tobin's Q is further winsorized at 10, as in, for example, Gompers, Lerner, and Scharfstein (2005).$^{18}$ Note that our sample varies drastically from the Survey of Small Business Finance (SSBF) previously analyzed in the context of the IBBEA (Rice and Strahan (2010)); in the Supplementary Material, we discuss these differences in more detail.

For the state-level analysis, we aggregate data from DealScan for which we can identify borrower states in either Compustat or the DealScan company file. In a few state-years, we cannot identify a single syndicated or bilateral loan and thus set the aggregate loan issuance variables to 0 . We scale total state-level issuance volumes over gross state product (GSP), which we retrieve from the Bureau of Economic Analysis (BEA). ${ }^{19}$ We further obtain data on all-transactions house prices from the Federal Housing Finance Agency (FHFA) and generate annual growth rates as the percentage change in end-of-year values. Real GSP growth comes from the BEA.

We also conduct an analysis at the bank-state-year level. Similar to the statelevel aggregates, we calculate the total syndicated and bilateral loan issuance of a lender in a given state as the total of loan issuance volume. ${ }^{20}$ We have more

\footnotetext{
${ }^{17}$ Note that the relatively high fraction of loans extended by commercial banks is not inconsistent with the increasing presence of nonbank intermediaries that has been documented in the leveraged loan market (see, e.g., Nandy and Shao (2010)). The reason the share of commercial banks syndicates is higher in our sample is because it also includes investment-grade loans.

${ }^{18}$ The results are not driven by these winsorization choices.

${ }^{19} \mathrm{We}$ adjust for the time-series break caused by the SIC/North American Industry Classification System (NAICS) transition in 1997 by chain-linking the overlapping series. We also winsorize these ratios at the 0.25 and 99.75 levels to account for a few outliers early in the syndicated loan time series, when the coverage is somewhat spottier. These adjustments do not drive our results.

${ }^{20}$ More precisely, we assign loan volumes to lenders based on the DealScan variable "bankallocation."
} 
TABLE 1

Descriptive Statistics

Table 1 provides descriptive statistics of the variables we use in the loan-level, bank-level, and state-level regressions. Data on the 14,102 loan facilities come from DealScan for the period 1987-2007. We construct lagged firm characteristics using Compustat Annual Fundamentals North America. Data on loan issuance at the bank-state level is constructed using DealScan and branch data from the Federal Deposit Insurance Corporation (FDIC). State-level variables are based on data from DealScan, FDIC, the Bureau of Economic Analysis (BEA), and the Federal Housing Finance Agency (FHFA). The Appendix provides more information on variable construction.

\begin{tabular}{|c|c|c|c|c|c|c|c|c|}
\hline & Mean & $\begin{array}{l}\text { 10th } \\
\text { Perc. } \\
\end{array}$ & $\begin{array}{l}25 \text { th } \\
\text { Perc. }\end{array}$ & $\begin{array}{l}\text { 50th } \\
\text { Perc. } \\
\end{array}$ & $\begin{array}{l}\text { 75th } \\
\text { Perc. } \\
\end{array}$ & $\begin{array}{l}\text { 90th } \\
\text { Perc. } \\
\end{array}$ & $\begin{array}{l}\text { Std. } \\
\text { Dev. }\end{array}$ & $N$ \\
\hline \multicolumn{9}{|c|}{ Interstate Branching Deregulation Index } \\
\hline DEREG & 0.639 & 0 & 0 & 1 & 1 & 1 & 0.480 & 14,102 \\
\hline \multicolumn{9}{|l|}{ Loan Characteristics } \\
\hline In(SPREAD) & 5.152 & 3.912 & 4.723 & 5.298 & 5.704 & 5.999 & 0.799 & 14,102 \\
\hline In(MATURITY) & 3.560 & 2.398 & 3.178 & 3.664 & 4.094 & 4.277 & 0.739 & 14,102 \\
\hline In(LOAN_SIZE) & 4.349 & 1.873 & 3.091 & 4.527 & 5.683 & 6.543 & 1.818 & 14,102 \\
\hline SECURED & 0.763 & 0 & 1 & 1 & 1 & 1 & 0.425 & 14,102 \\
\hline RELAT & 0.364 & 0 & 0 & 0 & 1 & 1 & 0.481 & 14,102 \\
\hline TERM_LOAN & 0.278 & 0 & 0 & 0 & 1 & 1 & 0.448 & 14,102 \\
\hline SYN & 0.795 & 0 & 1 & 1 & 1 & 1 & 0.403 & 14,102 \\
\hline COMM_BANK & 0.801 & 0 & 1 & 1 & 1 & 1 & 0.399 & 12,537 \\
\hline OOS_BANK & 0.624 & 0 & 0 & 1 & 1 & 1 & 0.484 & 5,174 \\
\hline \multicolumn{9}{|c|}{ Lagged Firm Characteristics } \\
\hline LEV & 0.343 & 0.040 & 0.170 & 0.313 & 0.468 & 0.635 & 0.257 & 14,102 \\
\hline $\mathrm{Q}$ & 1.425 & 0.585 & 0.779 & 1.073 & 1.596 & 2.480 & 2.210 & 14,102 \\
\hline In(ASSETS) & 5.947 & 3.471 & 4.545 & 5.927 & 7.289 & 8.460 & 1.921 & 14,102 \\
\hline ROA & 0.113 & 0.009 & 0.072 & 0.118 & 0.170 & 0.231 & 0.135 & 14,102 \\
\hline DTCF_NEG & 0.056 & 0 & 0 & 0 & 0 & 0 & 0.230 & 14,102 \\
\hline DTCF_HIGH & 0.435 & 0 & 0 & 0 & 1 & 1 & 0.496 & 14,102 \\
\hline SALE_GR & 1.023 & -0.124 & -0.004 & 0.100 & 0.278 & 0.623 & 34.911 & 14,102 \\
\hline RAT_DUM & 0.398 & 0 & 0 & 0 & 1 & 1 & 0.490 & 14,102 \\
\hline PPE & 0.321 & 0.067 & 0.138 & 0.266 & 0.459 & 0.678 & 0.229 & 14,102 \\
\hline \multicolumn{9}{|c|}{ Pre-Reform Borrower Characteristics } \\
\hline RATING & 9.953 & 6 & 7 & 10 & 12 & 14 & 3.398 & 1,865 \\
\hline PPE & 0.343 & 0.079 & 0.156 & 0.296 & 0.494 & 0.684 & 0.230 & 4,404 \\
\hline In(ASSETS) & 6.332 & 4.082 & 5.080 & 6.197 & 7.508 & 8.761 & 1.816 & 4,408 \\
\hline \multicolumn{9}{|l|}{ Bank-Level Variables } \\
\hline $\ln (1+$ SYN_LOAN_VOL) & 7.391 & 0 & 0 & 10.243 & 11.657 & 12.777 & 5.503 & 15,982 \\
\hline $\ln \left(1+B I L \_\right.$LOAN_VOL & 0.796 & 0 & 0 & 0 & 0 & 0 & 2.654 & 15,982 \\
\hline OOS_BANK & 0.841 & 0 & 1 & 1 & 1 & 1 & 0.366 & 15,982 \\
\hline \multicolumn{9}{|l|}{ State-Level Variables } \\
\hline SYN_LOAN_VOL_GDP & 0.048 & 0.000 & 0.005 & 0.027 & 0.068 & 0.119 & 0.067 & 1,479 \\
\hline BIL_LOAN_VOL_GDP & 0.005 & 0.000 & 0.000 & 0.002 & 0.006 & 0.015 & 0.010 & 1,479 \\
\hline HHI_1994 & 0.199 & 0.112 & 0.157 & 0.201 & 0.224 & 0.287 & 0.064 & 1,479 \\
\hline HP_GROWTH & 0.036 & -0.024 & 0.005 & 0.037 & 0.058 & 0.098 & 0.056 & 1,479 \\
\hline GDP_GROWTH & 0.025 & -0.006 & 0.009 & 0.023 & 0.041 & 0.059 & 0.028 & 1,428 \\
\hline
\end{tabular}

variation in syndicated loans because they are much more common in our sample than bilateral contracts. In the regressions, we use the natural logarithm of $1+$ issuance volume and adjust for inflation.

\section{Identification Strategy and Results}

In this section, we outline our empirical strategy and present our main results. We also provide an assessment of the validity of our empirical approach.

\section{A. Loan-Level Evidence}

To test the effect of the IBBEA on loan contracts, our starting point is the following difference-in-differences set-up:

$$
\begin{aligned}
\ln \left({\text { SPREAD })_{f}=}=\right. & \beta \text { DEREG }_{s t}+\gamma \text { BORROWER_CONTROLS }_{i, t-1} \\
& +\delta \text { CONTRACT_CONTROLS }_{f}+\alpha_{i}+\alpha_{t}+\varepsilon_{f},
\end{aligned}
$$


where $f, s, i$, and $t$ denote loan contract facilities, states, borrowers, and years, respectively. DEREG D $_{s t}$ is the $1 / 0$ dummy for IBBEA implementation described previously, which varies by state and date; BORROWER_CONTROLS ${ }_{i, t-1}$ is the vector of lagged borrower control variables; and CONTRACT CONTROLS Cis $_{f}$ the vector of contract-level controls. To absorb plausible within-correlation caused by the treatment effect (Petersen (2009)), we cluster standard errors by state.

The coefficient estimate $\hat{\beta}$ is supposed to capture the deregulation effect. The setup in equation (1), however, has the disadvantage that the IBBEA had a plethora of effects on the financial sector and local economies. This makes it difficult to pin down a specific channel. To narrow down the substitution effect of the IBBEA, we thus use a triple-difference strategy. In its most saturated form, this is similar in spirit to Jiménez, Ongena, Peydró, and Saurina (2014) and Khwaja and Mian (2008). In particular, we allow for differential treatment impact by interacting the dummy DEREG $s t$ with contract details $\mathrm{EXP}_{f}$, which allows us to fully absorb time-varying borrower $\times$ year and bank $\times$ year factors with fixed effects, yielding the following:

$$
\begin{aligned}
& \ln \left(\mathrm{SPREAD}_{f}=\beta_{1} \mathrm{DEREG}_{s t}+\beta_{2} \mathrm{DEREG}_{s t} \times \mathrm{EXP}_{f}+\beta_{3} \mathrm{EXP}_{f}\right. \\
& \quad+\gamma \mathrm{BORROWER} C O N T R O L S_{i, t-1}+\delta \mathrm{CONTRACT}_{-} \mathrm{BONTROLS}_{f} \\
& \quad+\alpha_{i t}+\alpha_{b t}+\varepsilon_{f},
\end{aligned}
$$

where $b$ stands for banks, which we identify as a loan's lead arranger, as is standard in the literature. Using interacted fixed effects $\alpha_{i t}$ and $\alpha_{b t}$ intuitively means that we compare loans issued by the same borrower in the same year while also taking out unobserved time-varying bank factors. This is important in our setting because it rules out that borrower or bank fundamentals unrelated to the loan-level variation drive our results.

We use different variables for $\mathrm{EXP}_{f}$. First, we use a dummy for syndicated loans to directly test our substitution hypothesis. Second, we use a dummy variable for loans where the lead arranger is a commercial bank, and thus legally affected by the reform, within the group of syndicated loans. Third, we use a dummy for out-of-state banks within the group of syndicated loans issued by commercial banks (also see Favara and Imbs (2015)). We discuss these exposure variables in more detail momentarily.

The identifying assumption underlying our empirical specification is not that "exposed" loans are similar in observable or unobservable characteristics to those that are "not exposed." Rather, the assumption is that their interest rate spreads would have trended similarly in the absence of state-level branching deregulation. This assumption is supported by two pieces of evidence. First, although syndicated and bilateral loans differ in their typical loan terms, there are no consistent differences between syndicated loans issued by commercial banks versus other lenders or out-of-state versus in-state commercial banks (see Figure 5). Because we also exploit variation in lender types within the group of syndicated loans, we are unlikely to capture a deregulation effect that works through other loan characteristics. Second, and perhaps most important, spreads showed a similar trajectory for "exposed" and "not exposed" loans in the years prior to deregulation, as we show in the following discussion. That is, they showed no change in spreads 
until after the implementation of the IBBEA. We discuss these and other threats to identification in more detail in the following discussion and in Section IV.D.

Equipped with our empirical strategy, we begin by running the baseline regression in equation (1), meaning we regress a loan facility's interest rate spread on the DEREG dummy and borrower and year fixed effects as well as control variables. Column 1 in Table 2 plots the results. Recall that the clear majority of contracts in our sample are syndicated. The estimated coefficient is positive and highly statistically significant, with a point estimate of 0.054 . Because the dependent variable is measured in natural logarithm, we use the Taylor series approximation throughout the article to translate log points into percentage changes to help the interpretation of our findings. An increase in $5.4 \log$ points thus represents an increase of approximately $5.4 \%$ in interest rate spreads, which is equivalent to a small increase of approximately 11 basis points (bps) from the median spread of 200 bps (see the summary statistics in Table 1).

TABLE 2

The Effect of Deregulation on Syndicated and Bilateral Loan Spreads

Table 2 reports the results of regressing the interest rates spreads of syndicated loans (in natural logarithm) on DEREG, a dummy that equals 1 if a state has lifted one or more branching restrictions, and 0 otherwise, and interaction variables. SYN is a dummy for loans with more than one creditor. COMM_BANK is a dummy equal to 1 for commercial banks (i.e., lenders with a Standard Industrial Classification (SIC) code starting with 602), and 0 for other lenders where industry classification is available. OOS BANK refers to banks without branches in the borrower's state prior to implementation of the Interstate Banking and Branching Efficiency Act (IBBEA). The sample in columns 4 and 5 is restricted to syndicated loans only, and the sample in columns 6 and 7 is restricted to syndicated loans issued by commercial banks, as indicated by the $\checkmark$. "-" indicates absorbed estimates. See the text for included control variables. Robust standard errors (in parentheses) are clustered at the state level. *, ${ }^{* *}$, and ${ }^{* * *}$ indicate statistical significance at the $10 \%, 5 \%$, and $1 \%$ levels.

\begin{tabular}{|c|c|c|c|c|c|c|c|}
\hline & \multirow{3}{*}{$\begin{array}{c}\begin{array}{c}\text { Borrower } \\
\text { FE }\end{array} \\
\frac{\text { (Baseline) }}{1} \\
\end{array}$} & \multicolumn{6}{|c|}{ Exposure Variable } \\
\hline & & \multicolumn{2}{|c|}{ SYN } & \multicolumn{2}{|c|}{ COMM_BANK } & \multicolumn{2}{|c|}{ OOS_BANK } \\
\hline & & 2 & 3 & 4 & 5 & 6 & 7 \\
\hline DEREG & $\begin{array}{l}0.054^{* *} \\
(0.025)\end{array}$ & $\begin{array}{l}-0.073^{\star * *} \\
(0.026)\end{array}$ & - & $\begin{array}{c}-0.049 \\
(0.052)\end{array}$ & - & $\begin{array}{c}-0.107 \\
(0.068)\end{array}$ & - \\
\hline DEREG $\times$ EXP & & $\begin{array}{l}0.095^{* * *} \\
(0.302)\end{array}$ & $\begin{array}{c}0.122^{*} \\
(0.065)\end{array}$ & $\begin{array}{l}0.120^{* *} \\
(0.051)\end{array}$ & $\begin{array}{l}0.248^{\star \star} \\
(0.109)\end{array}$ & $\begin{array}{l}0.204^{* * \star} \\
(0.079)\end{array}$ & $\begin{array}{l}0.609^{\star \star \star} \\
(0.180)\end{array}$ \\
\hline EXP & & $\begin{array}{l}-0.139^{\star * *} \\
(0.025)\end{array}$ & $\begin{array}{r}-0.087^{\star} \\
(0.052)\end{array}$ & $\begin{array}{l}-0.172^{\star \star *} \\
(0.052)\end{array}$ & - & $\begin{array}{c}-0.126 \\
(0.073)\end{array}$ & $\begin{array}{c}-0.231 \\
(0.229)\end{array}$ \\
\hline $\begin{array}{l}\text { Loan controls } \\
\text { Borrower controls } \\
\text { Borrower FE } \\
\text { Year FE } \\
\text { Borrower } \times \text { year FE } \\
\text { Bank } \times \text { year FE } \\
\text { Only syndicated loans } \\
\text { Only commercial banks }\end{array}$ & $\begin{array}{l}\text { Yes } \\
\text { Yes } \\
\text { Yes } \\
\text { Yes }\end{array}$ & $\begin{array}{l}\text { Yes } \\
\text { Yes } \\
\text { Yes } \\
\text { Yes }\end{array}$ & $\begin{array}{c}\text { Yes } \\
- \\
- \\
- \\
\text { Yes } \\
\text { Yes }\end{array}$ & $\begin{array}{l}\text { Yes } \\
\text { Yes } \\
\text { Yes } \\
\text { Yes }\end{array}$ & $\begin{array}{c}\text { Yes } \\
- \\
- \\
- \\
\text { Yes } \\
\text { Yes } \\
\checkmark\end{array}$ & $\begin{array}{l}\text { Yes } \\
\text { Yes } \\
\text { Yes } \\
\text { Yes }\end{array}$ & $\begin{array}{c}\text { Yes } \\
- \\
- \\
- \\
\text { Yes } \\
\text { Yes } \\
\checkmark \\
\checkmark\end{array}$ \\
\hline $\begin{array}{l}\text { No. of obs. } \\
\text { Adj. } R^{2}\end{array}$ & $\begin{array}{r}14,102 \\
0.819\end{array}$ & $\begin{array}{r}14,102 \\
0.820\end{array}$ & $\begin{array}{l}9,703 \\
0.951\end{array}$ & $\begin{array}{l}9,689 \\
0.842\end{array}$ & $\begin{array}{l}6,992 \\
0.958\end{array}$ & $\begin{array}{l}3,148 \\
0.886\end{array}$ & $\begin{array}{l}2,212 \\
0.967\end{array}$ \\
\hline
\end{tabular}

We next attempt to strengthen these baseline results by exploiting differential exposure of borrowers to the reform (as in equation (2)). If our substitution hypothesis is correct, we would expect that interstate branching had markedly different effects on syndicated and bilateral loan pricing. We run a direct test in column 2 of Table 2, where we introduce a dummy for whether a loan is syndicated and interact it with the DEREG treatment dummy. The interaction term DEREG $\times S Y N$ enters positively with a coefficient of 0.095 ; it is -0.073 for the deregulation 
measure itself. Both estimates are highly statistically significant. This implies that interest rates increased almost exclusively on loans with more than a single creditor: The effect on "bilateral loans" was a sizeable 7.3\% decrease, whereas syndicated loan spreads increased by $0.095-0.073=2.2 \%$. The loan-level variation of the treatment effect also allows for the inclusion of a full set of interacted fixed effects in column 3, where the triple-difference effect increases to 0.122 . This suggests that unobserved time-varying factors at the bank or borrower levels do not drive our results.

Could it be that other loan characteristics that happen to correlate with syndication drive these results? To get around this issue, we exploit the nature of interstate branching laws to conduct a simple test based on bank types. The IBBEA only altered restrictions on cross-state branching for commercial banks and did not apply to other lenders (Johnson and Rice (2008), Favara and Imbs (2015)). We thus treat commercial banks as "affected" and other lenders as "unaffected" within the group of syndicated loans. Commercial bank loans in our sample show considerably fewer differences from nonbank loans compared with the syndicatedbilateral split. ${ }^{21}$ If we are indeed correct that spreads increased due to a substitution effect between local branches and syndication, only institutions affected by the changes in regulation should react. Indeed, previous work by Favara and Imbs (2015) and Rice and Strahan (2010) suggests that the impact on unaffected lenders should be a reduction in rates due to the increase in competition.

We test this by again running equation (2), this time interacting DEREG with a dummy for whether a lender is classified as a commercial bank. The result is reported in column 4 of Table 2. The interaction term now has an estimated coefficient of 0.120 , which is significant at the 5\% level. Again, the DEREG dummy itself now turns negative with a value of -0.049 . Although it is imprecisely estimated, this suggests a decrease in interest rates for loans issued by lenders other than commercial banks. It is instructive to compare these estimates with the baseline estimate in column 1. Our estimates suggest that deregulation increased spreads for affected lenders by $0.120-0.049 \approx 7.1 \log$ points, which is close to the baseline estimate in column 1. The deregulation-induced increase in spreads thus appears to be largely driven by directly affected institutions. The triple-difference specification also lets us absorb demand- or risk-based explanations by including a full vector of borrower $\times$ year and bank $\times$ year dummies in column 5 . The interaction term DEREG $\times$ EXP is again significant at the $5 \%$ level and approximately doubles in size.

Next, we turn to variation within the group of syndicated loans issued by the affected commercial banks by comparing out-of-state versus in-state banks. Intuitively, we would expect that banks with a local presence before the reform were subject to greater competition from out-of-state banks entering the market, which should drive down interest rates. The increase in spreads we uncover, in turn, should be driven by out-of-state banks because these were able to acquire or erect branching networks following IBBEA implementation (Favara and Imbs (2015)), decreasing the need to use loan syndication to geographically diversify their loan portfolios.

\footnotetext{
${ }^{21}$ We discuss these differences in more detail in Section IV.D.
} 
We test these predictions in columns 6 and 7 of Table 2 by interacting our treatment dummy DEREG with a dummy for out-of-state banks, which we define as commercial banks without a branch in the borrower state in the pre-reform year. The approach has the important advantage that all lenders in the sample are, at some point, out-of-state banks. To illustrate, a bank that is classified as "outof-state" in New York will be an "in-state" bank in Utah if it had a local presence there before the IBBEA. As a result, loans issued by the two types of commercial banks are observationally equivalent (see Figure 5).

The interacted coefficients for both estimations are positive and highly statistically significant. Again, the DEREG dummy itself turns negative, suggesting that, if anything, spreads decreased for lenders with local branch presences prior to IBBEA implementation. The effect for out-of-state banks, however, was a positive increase in loan rates of $-0.107+0.204=0.097$, or $9.7 \%$. This effect becomes much larger if we allow for borrower $\times$ year and bank $\times$ year fixed effects in column 7 of Table 2, which absorbs all time-varying demand or risk factors. This result is consistent with a substitution effect of syndicated for bilateral loans by out-of-state lenders.

A potential concern at this point may be that state-level trends in spreads may have already been different prior to IBBEA implementation. In technical terms, this would constitute a violation of the parallel-trends assumption required for causal inference from difference-in-differences estimates. Such preexisting trends could be the result, for example, of the process of intrastate branching and interstate banking deregulation that had been unfolding starting in the 1970 s (see, e.g., Kroszner and Strahan (2014)).

Figure 2 investigates this possibility for syndicated versus bilateral loans. We plot the estimates for the interaction of the syndicated loan dummy with year dummies around the deregulation date. In particular, we consider 7 years before and after a state lifted its first branching restriction. The results suggest that there was no discernible trend in interest rates before interstate deregulation and that the positive effect we uncovered in Table 2 developed relatively quickly over a few years after implementation, in line with previous evidence on branching deregulation (e.g., Beck et al. (2010), Chava et al. (2013)). ${ }^{22}$

We also use a regression framework to test for preexisting trends. Here, we differentiate between the time periods immediately before and after the reform as well as long-term effects. Table 3 plots the estimates from this exercise. In column 1 , we see that spreads in the period immediately before state deregulation $(t-4$ to $t-1)$ did not change compared to before: The coefficient of 0.029 is small and clearly statistically insignificant. Spreads did change, however, immediately after IBBEA implementation. The coefficients of 0.095 and 0.114 for the periods after implementation are considerably larger and statistically significant at the $5 \%$ and $10 \%$ levels, respectively.

\footnotetext{
${ }^{22} \mathrm{~A}$ small lag in the effect should be expected because market entry takes time. Neither identifying possible new locations for new branches nor acquiring and integrating existing banks can be organized quickly. In anti-merger antitrust lawsuits, the U.S. Department of Justice and the Federal Trade Commission usually mention 2 years as the minimum time it takes to enter markets in most industries.
} 
FIGURE 2

IBBEA Implementation and the Spreads of Syndicated versus Bilateral Loans

Figure 2 plots the coefficient estimates of $\hat{\beta}_{2}^{h}$ of the regression

$$
\begin{aligned}
\ln (\operatorname{SPREAD})_{f}= & \sum_{h=-7}^{7} \beta_{1}^{h} \mathrm{DEREG}_{s t}+\sum_{h=-7}^{7} \beta_{2}^{h} \mathrm{DEREG}_{s t} \times \text { EXP }_{f}+\beta_{3} \text { EXP }_{f}+\gamma \text { BORROWER_CONTROLS }_{i, t-1} \\
& +\delta \text { CONTRACT_CONTROLS } \\
f & +\alpha_{i}+\alpha_{b}+\alpha_{t}+\varepsilon_{f},
\end{aligned}
$$

where $\sum_{h=-7}^{7} D_{s t}$ is a set of dummy variables for the 7 years before to 7 years after the date of Interstate Banking and Branching Efficiency Act (IBBEA) implementation. Confidence intervals are based on the $90 \%$ significance level, with standard errors clustered at the state level. We exclude facilities that are most likely structured for institutional investors, as in column 9 of Table A5 in the Supplementary Material.

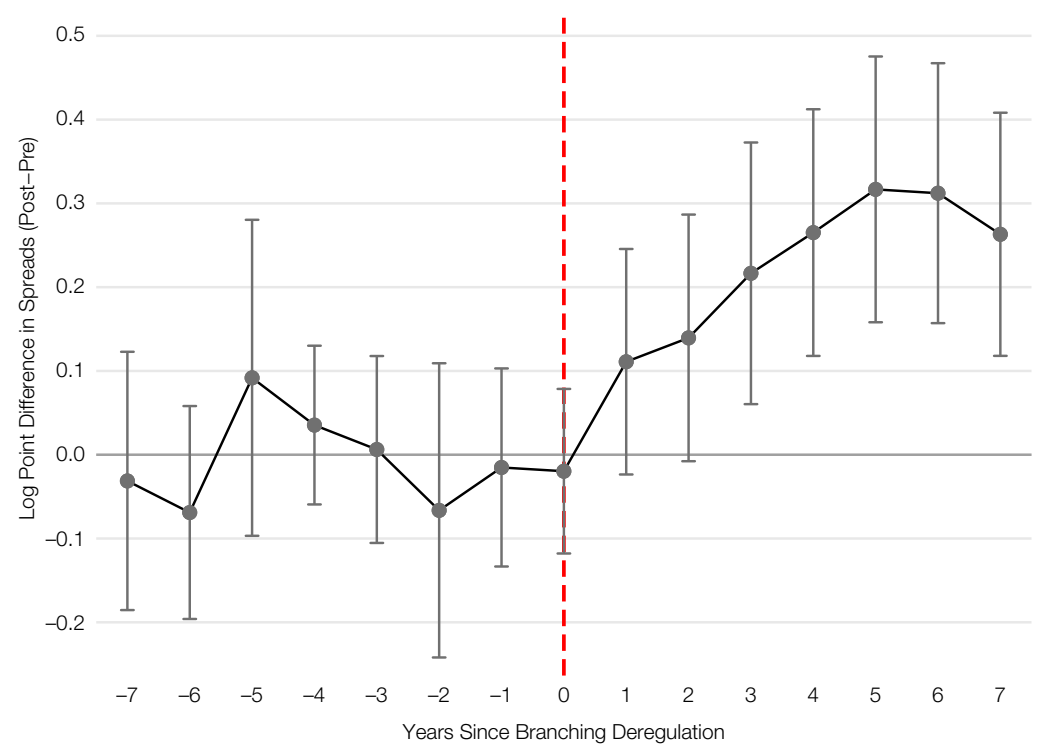

In columns 2-4 of Table 3, we find a similar pattern for the interaction terms of DEREG with syndicated loans, affected lenders, and out-of-state commercial banks. These results are easily summarized by $F$-tests for the equality of coefficients between the time periods, reported at the bottom of the table. ${ }^{23}$ In all regressions, the tests imply that the coefficients for the period of more than 5 years before IBBEA implementation (DEREG $(\leq t-5))$ are not statistically different from those for the period immediately before the reform (DEREG $(t-4 ; t-1)$ ). This is consistent with the absence of preexisting trends, irrespective of potential differences in the level of interest rates between loan types. When we test for the equality of coefficients for the pre- versus post-implementation periods, the null hypothesis of no difference is strongly rejected, with values for the $F$-statistic between 4.5 and 27. Taken together, this suggests the discount on the spreads of syndicated loans disappeared after branching deregulation but not before.

What do our results imply about the lending conditions of corporations postIBBEA? At first glance, it might appear puzzling that the interest rate spreads of

\footnotetext{
${ }^{23}$ Note that this test is equivalent to the $t$-test of statistical significance in column 1 of Table 3 . To aid readability, we thus only report the $F$-statistic for the interaction terms of interest in columns $2-4$.
} 
Parallel Trends in Spreads Before Branching Deregulation

Table 3 reports the results from regressions of interest rates spreads (in natural logarithm) on DEREG, a dummy that equals 1 if a state has lifted one or more branching restrictions. The excluded category is DEREG $(\leq t-5)$. SYN is a dummy for loans with more than one creditor. COMM_BANK is a dummy equal to 1 for commercial banks (i.e., lenders with a Standard Industrial Classification (SIC) code starting with 602), and 0 for other lenders where industry classification is available. OOS_BANK refers to banks without branches in the borrower's state prior to implementation of the Interstate Banking and Branching Efficiency Act (IBBEA). Column 3 limits the sample to syndicated loans, and column 4 limits the sample to syndicated loans by commercial banks, as indicated by the $\checkmark$. Note that the interaction with COMM_BANK in column 4 is absorbed by the bank fixed effects (FE). The bottom two columns report the $F$-statistics for the equality of the indicated coefficients; insignificant values indicate no difference. Robust standard errors (in parentheses) are clustered by states. ${ }^{*}{ }^{* *}$, and ${ }^{* *}$ indicate statistical significance at the $10 \%, 5 \%$, and $1 \%$ levels, respectively.

\begin{tabular}{|c|c|c|c|c|}
\hline & \multirow[b]{2}{*}{ Baseline } & \multicolumn{3}{|c|}{ Exposure Variable } \\
\hline & & SYN & $\begin{array}{c}\text { COMM_ } \\
\text { BANK } \\
\end{array}$ & $\begin{array}{l}\text { OOS }_{-} \\
\text {BANK }\end{array}$ \\
\hline & 1 & 2 & 3 & 4 \\
\hline DEREG $(\leq t-5)$ & - & - & - & - \\
\hline DEREG $(t-4 ; t-1)$ & $\begin{array}{c}0.029 \\
(0.023)\end{array}$ & $\begin{array}{l}0.017 \\
(0.038)\end{array}$ & $\begin{array}{c}0.085 \\
(0.108)\end{array}$ & $\begin{array}{c}0.047 \\
(0.083)\end{array}$ \\
\hline DEREG $(t ; t+3)$ & $\begin{array}{l}0.095^{\star *} \\
(0.040)\end{array}$ & $\begin{array}{c}-0.005 \\
(0.048)\end{array}$ & $\begin{array}{c}-0.045 \\
(0.111)\end{array}$ & $\begin{array}{c}0.004 \\
(0.123)\end{array}$ \\
\hline DEREG $(\geq t+4)$ & $\begin{array}{c}0.114^{*} \\
(0.061)\end{array}$ & $\begin{array}{c}-0.105 \\
(0.064)\end{array}$ & $\begin{array}{c}-0.031 \\
(0.117)\end{array}$ & $\begin{array}{c}-0.039 \\
(0.128)\end{array}$ \\
\hline $\operatorname{DEREG}(\leq t-5) \times \operatorname{EXP}$ & & $\begin{array}{l}-0.163^{\star \star \star} \\
(0.038)\end{array}$ & - & $\begin{array}{c}-0.098 \\
(0.088)\end{array}$ \\
\hline $\operatorname{DEREG}(t-4 ; t-1) \times \operatorname{EXP}$ & & $\begin{array}{l}-0.159^{\star * \star} \\
(0.031)\end{array}$ & $\begin{array}{c}-0.048 \\
(0.103)\end{array}$ & $\begin{array}{c}-0.141 \\
(0.094)\end{array}$ \\
\hline $\operatorname{DEREG}(t ; t+3) \times \operatorname{EXP}$ & & $\begin{array}{r}-0.055^{*} \\
(0.032)\end{array}$ & $\begin{array}{l}0.165^{\star} \\
(0.100)\end{array}$ & $\begin{array}{c}0.028 \\
(0.040)\end{array}$ \\
\hline $\operatorname{DEREG}(\geq t+4) \times \operatorname{EXP}$ & & $\begin{array}{l}0.069^{\star \star \star} \\
(0.026)\end{array}$ & $\begin{array}{c}0.164 \\
(0.100)\end{array}$ & $\begin{array}{l}0.112^{\star \star \star} \\
(0.042)\end{array}$ \\
\hline $\begin{array}{l}\text { Loan controls } \\
\text { Borrower controls } \\
\text { Borrower FE } \\
\text { Bank FE } \\
\text { Year FE } \\
\text { Only syndicated loans } \\
\text { Only commercial banks }\end{array}$ & $\begin{array}{l}\text { Yes } \\
\text { Yes } \\
\text { Yes } \\
\text { Yes } \\
\text { Yes }\end{array}$ & $\begin{array}{l}\text { Yes } \\
\text { Yes } \\
\text { Yes } \\
\text { Yes } \\
\text { Yes }\end{array}$ & $\begin{array}{l}\text { Yes } \\
\text { Yes } \\
\text { Yes } \\
\text { Yes } \\
\text { Yes } \\
\checkmark\end{array}$ & $\begin{array}{l}\text { Yes } \\
\text { Yes } \\
\text { Yes } \\
\text { Yes } \\
\text { Yes } \\
\checkmark \\
\checkmark\end{array}$ \\
\hline $\begin{array}{l}\text { No. of obs. } \\
\text { Adj. } R^{2}\end{array}$ & $\begin{array}{r}13,437 \\
0.848\end{array}$ & $\begin{array}{r}13,437 \\
0.849\end{array}$ & $\begin{array}{l}9,596 \\
0.861\end{array}$ & $\begin{array}{l}3,134 \\
0.895\end{array}$ \\
\hline $\begin{aligned} H_{0} & : \operatorname{DEREG}(\leq t-5) \times \operatorname{EXP} \\
& =\operatorname{DEREG}(t-4 ; t-1) \times \operatorname{EXP}\end{aligned}$ & & 0.01 & 0.21 & 0.28 \\
\hline $\begin{aligned} H_{0} & : \text { DEREG }\left(\sum \text { pre }\right) \times \operatorname{EXP} \\
& =D E R E G\left(\sum \text { post }\right) \times \operatorname{EXP}\end{aligned}$ & & $27.14^{\star \star \star}$ & $7.94^{\star \star *}$ & $4.56^{* *}$ \\
\hline
\end{tabular}

large borrowers with access to capital markets should increase because of changes to local banking regulations. However, our sample statistics suggest that even after branching deregulation, syndicated loans still remained considerably cheaper than bilateral contracts. Consider, by way of example, a typical loan facility in our sample: a secured revolving loan with a 5-year maturity. The data indicate that the unconditional average spread on such a contract increased from approximately 180 to 200 bps but decreased from 310 to $300 \mathrm{bps}$ for bilateral loans. This suggests a decreased discount for syndicated loans, rather than an increase in borrowing costs per se. The average interest rate increase also reflects the sample composition: $80 \%$ of the loan contracts we observe are syndicated, compared with approximately $50 \%$ of U.S. corporate loans.

Another illustration of the estimated magnitudes is the differences in basis points after controlling for our baseline controls (as in equation (1)). This exercise 
suggests that spreads increased almost exclusively for syndicated loans issued by out-of-state commercial banks. Even after controlling for fundamentals, this increase is sizable: approximately $11 \mathrm{bps}$ for the same borrower. The spreads for bilateral loans went down throughout, consistent with more competition, as did those for syndicated loans issued by lenders other than commercial banks. The only other interest rate increase in the data is for syndicated loans issued by instate commercial banks, on the order of 3.5 bps. This is likely explained by the fact that all banks are an in-state bank somewhere and are thus subject to spillover effects; competition from out-of-state lenders may have further heightened instate banks' willingness to underwrite loans by themselves, leading to a decline in syndicated loan supply. Most importantly, the effect on in-state banks is much smaller than that on out-of-state banks. The increased rates we observe in the data should thus be interpreted as a reallocation from syndicated to sole lender loans, rather than an increase in the cost of credit.

Taken together, we find that the effect of branching deregulation increases with exposure to the reforms. Importantly, our results are fully driven by affected lenders and syndicated loans, in line with our predictions. If anything, our estimates imply a decrease in spreads for bilateral loans. These findings are consistent with the idea that syndication can be a substitute for direct lending through local branches to achieve geographical diversification.

\section{B. Bank-Level Regressions}

Up to this point, we have focused on the effect of interstate branching on spreads. In this section, we provide some evidence that banks also reshuffled their loan portfolios and replaced at least some syndicated with bilateral loans.

More specifically, we run an analysis at the bank-state-year level, which allows us to absorb a full set of bank $\times$ state, bank $\times$ year, and state $\times$ year dummies. By way of example, this means comparing borrowers in Alabama in 1999 with other Bank of America customers in 1999, depending on whether the state was deregulated and the bank exposed to the reform changes. In particular, our substitution hypothesis implies that out-of-state banks without a local branch presence prior to the state-level IBBEA reforms used loan syndication to diversify geographical credit risk. After interstate branching was allowed, these institutions could enter other state markets and open or acquire branches, which allowed for the issuance of bilateral loans.

More formally, we regress loan issuance by a given bank in a given state and year on the DEREG dummy, interacted with a dummy for commercial banks with a local branch presence prior to the reform ("out-of-state bank" (OOS_BANK)):

$$
\begin{aligned}
\text { LOAN_VOL }_{b s t}= & \beta_{1} \text { DEREG }_{s t}+\beta_{2} \text { DEREG }_{s t} \times \text { OOS_BANK } \\
& +\beta_{3} \text { OOS_BANK } \\
b s & +\alpha_{b t}+\alpha_{s t}+\varepsilon_{b s t},
\end{aligned}
$$

where $b$ indexes banks, $s$ states, and $t$ years. LOAN_VOL is the natural logarithm of loan-issuance volumes, referring either to syndicated or bilateral loans. ${ }^{24}$ OOS_BANK $_{b s}$ is a dummy for out-of-state banks without a local branch presence

\footnotetext{
${ }^{24}$ We assign 0 issuance to all bank-state-year observations between the first and last loan a bank has in a state for which we do not have any loan data.
} 
before the reform, which should drive the substitution effect we outlined earlier. In the most stringent specification, our fixed effects absorb time-varying shocks to banks and individual states (e.g., to local demand or bank health). Standard errors are double-clustered at the bank and state level. This clustering choice allows for error correlations within states (across banks) and within banks (across states). ${ }^{25}$

The results in Table 4 illustrate that, consistent with our hypothesis, syndicated loan issuance contracted and bilateral volume expanded for banks that were not present before the deregulation but were able to enter ex post. In column 1, we show that interstate branching reduced average syndicated loan issuance at the bank level. The estimate of -0.299 implies an average decrease in issuance of approximately $30 \log$ points. Next, we analyze the impact on commercial banks depending on whether they had a local branch presence prior to IBBEA implementation, implying that they could lend directly to local customers through their branches. The coefficients in column 2 indicate a large effect on out-of-state banks: Branching deregulation increased syndicated lending by $69 \log$ points for in-state banks under competitive pressure but decreased it by $49.1 \mathrm{log}$ points for out-of-state banks $(-1.181+0.690=0.491)$. The interaction term is still statistically significant when we include interacted fixed effects in column 3, implying that it is not driven by changes in demand or aggregate bank-level shocks. This aligns with previous evidence that lifting restrictions increased credit supply. For syndicated loans, however, it suggests a contraction for lending by out-of-state banks, which could lend to local markets via their expanded branching networks post-IBBEA.

\section{TABLE 4}

The Effect of Deregulation on Banks' Loan Issuance, by State and Year

\begin{tabular}{|c|c|c|c|c|c|c|}
\hline & \multicolumn{3}{|c|}{ Syndicated Loan Volume } & \multicolumn{3}{|c|}{ Bilateral Loan Volume } \\
\hline & 1 & 2 & 3 & 4 & 5 & 6 \\
\hline DEREG & $\begin{array}{c}-0.299 \\
(0.333)\end{array}$ & $\begin{array}{c}0.690^{*} \\
(0.401)\end{array}$ & & $\begin{array}{c}-0.051 \\
(0.063)\end{array}$ & $\begin{array}{l}-1.159^{\star \star \star} \\
(0.296)\end{array}$ & \\
\hline DEREG $\times$ OOS_BANK & & $\begin{array}{l}-1.181^{\star \star *} \\
(0.237)\end{array}$ & $\begin{array}{l}-0.598^{\star \star} \\
(0.239)\end{array}$ & & $\begin{array}{l}0.994^{\star \star *} \\
(0.349)\end{array}$ & $\begin{array}{c}0.526 \\
(0.340)\end{array}$ \\
\hline OOS_BANK & & $\begin{array}{l}-1.156^{\star * *} \\
(0.222)\end{array}$ & 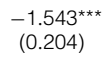 & & $\begin{array}{l}-1.570^{\star * *} \\
(0.370)\end{array}$ & $\begin{array}{c}-1.296^{\star \star \star} \\
(0.369)\end{array}$ \\
\hline $\begin{array}{l}\text { Bank FE } \\
\text { State FE } \\
\text { Year FE } \\
\text { Bank } \times \text { year FE } \\
\text { State } \times \text { year FE }\end{array}$ & $\begin{array}{l}\text { Yes } \\
\text { Yes } \\
\text { Yes }\end{array}$ & $\begin{array}{l}\text { Yes } \\
\text { Yes } \\
\text { Yes }\end{array}$ & $\begin{array}{c}- \\
- \\
- \\
\text { Yes } \\
\text { Yes }\end{array}$ & $\begin{array}{l}\text { Yes } \\
\text { Yes } \\
\text { Yes }\end{array}$ & $\begin{array}{l}\text { Yes } \\
\text { Yes } \\
\text { Yes }\end{array}$ & $\begin{array}{c}- \\
- \\
- \\
\text { Yes } \\
\text { Yes }\end{array}$ \\
\hline $\begin{array}{l}\text { No. of obs. } \\
R^{2}\end{array}$ & $\begin{array}{r}50,727 \\
0.338\end{array}$ & $\begin{array}{r}13,751 \\
0.307\end{array}$ & $\begin{array}{r}13,462 \\
0.528\end{array}$ & $\begin{array}{r}50,727 \\
0.224\end{array}$ & $\begin{array}{r}13,751 \\
0.221\end{array}$ & $\begin{array}{r}13,462 \\
0.357\end{array}$ \\
\hline
\end{tabular}

To get a more complete picture, we rerun the analysis using bilateral loan issuance as a dependent variable in columns 4-6 of Table 4. On average, we do

\footnotetext{
${ }^{25}$ In unreported results, we find that clustering at the state level makes little difference in the statistical significance in our setting.
} 
not find a statistically significant effect in column 4. However, whether banks had a branching presence prior to a state implementing the IBBEA clearly matters, as shown by the highly significant coefficients in column 5. In particular, the coefficient on DEREG itself is negative $(-1.159)$, but it is positive and of similar magnitude for the interaction with the out-of-state bank dummy (0.994). This shows that banks reallocated their bilateral loan issuance from states where they were already present before the IBBEA to newly opened states, where the overall impact was likely small. In column 6 , we replicate this result using a much more stringent set of fixed effects.

These results are also confirmed by the graphical evidence in Figure 3, where we allow for a dynamic effect of deregulation around the implementation year. More precisely, we rerun equation (3) but replace DEREG $_{s t}$ with a set of dummy variables for the years around a state's IBBEA implementation. On impact, but not before, out-of-state banks decreased their syndicated loan issuance in deregulated states and sharply increased their bilateral lending.

Overall, the results presented here increase our confidence in the idea of a "substitution channel" triggered by syndication becoming a less profitable way to diversify geographical credit risk, leading banks to a reshuffle their loan portfolios.

\section{State-Level Regressions}

The results in the previous sections reveal that interstate branching deregulation was followed by a shift from syndicated to bilateral lending. But were these effects large enough to matter at the state level as well? In this section, we provide some evidence based on cross-sectional exposure to the IBBEA induced by the degree of local market concentration prior to the reform. Although we cannot rule out that unobserved time-varying state- or bank-level factors partially drive these results, they are useful for thinking about the aggregate effects of banking deregulation.

Intuitively, one would expect that the IBBEA had a larger impact on states with lower initial competition among banks, an insight that Black and Strahan (2002) and Cetorelli and Strahan (2006) find to be true for earlier deregulatory episodes in the United States. Graph A of Figure 4 shows that the same pattern holds for interstate branching deregulation, where we plot a state's HHI of deposits in 1994 (before the IBBEA) against the log-change in the number of branches after its implementation. ${ }^{26}$ The data suggest that the branching effect uncovered by Favara and Imbs (2015) strongly interacts with the pre-reform HHI: After deregulation, banks opened considerably more branches in states that previously had more concentrated markets. In the Supplementary Material, we show that a similar pattern holds for changes to competition post-IBBEA. These correlations also persist in simple ordinary least squares (OLS) regressions (Table A4 of the Supplementary Material).

\footnotetext{
${ }^{26}$ These graphs omit Hawaii and Rhode Island, which are clear outliers. The figures look very similar when these are included. Because the number of branches is a highly persistent variable, the results are also not sensitive to the exact time horizon.
} 
FIGURE 3

Deregulation and Banks' Loan Issuance, by State and Year

Figure 3 provides graphical evidence for changes in syndicated and bilateral loan issuance around a state's implementation of the Interstate Banking and Branching Efficiency Act (IBBEA). We plot the $\hat{\beta}_{2}^{h}$ coefficients of regressions

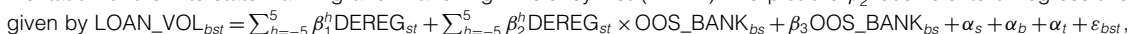
where $h$ indexes the year relative to deregulation. Graph A plots the results for syndicated loan issuance, and Graph B plots the results for bilateral loan issuance (both measured as the natural logarithm of $1+$ loan volume).
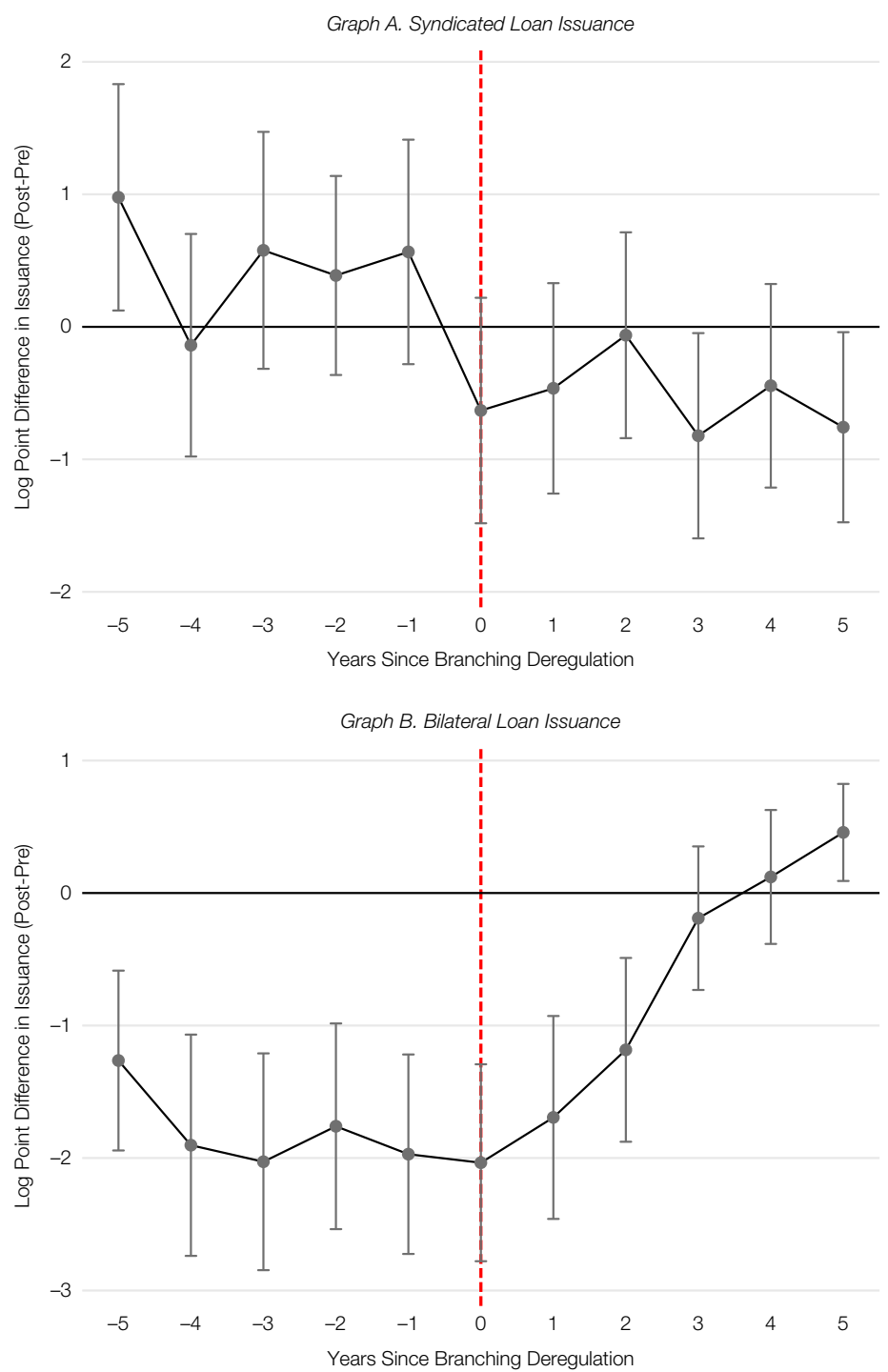

Graph B of Figure 4 next plots the evolution of syndicated loan issuance around IBBEA implementation at the state level. We scale issuance volumes by state gross domestic product (GDP) and show median values plus $90 \%$ confidence intervals. This reveals a striking pattern. Before deregulation, there was a clear 
FIGURE 4

Pre-Reform HHI, IBBEA Implementation, and Syndicated Loan Issuance

Graph A of Figure 4 plots a state's deposit Herfindahl-Hirschman index (HHI) in 1994 (deposit-weighted county average) against the post-deregulation change in the log number of branches (we omit the outliers Hawaii and Rhode Island). Graph B plots the median and $90 \%$ confidence intervals of total state-level syndicated loan issuance in the DealScan database around the first date a state lifted any of the branching restrictions identified in Rice and Strahan (2010), scaled by state gross domestic product (GDP).
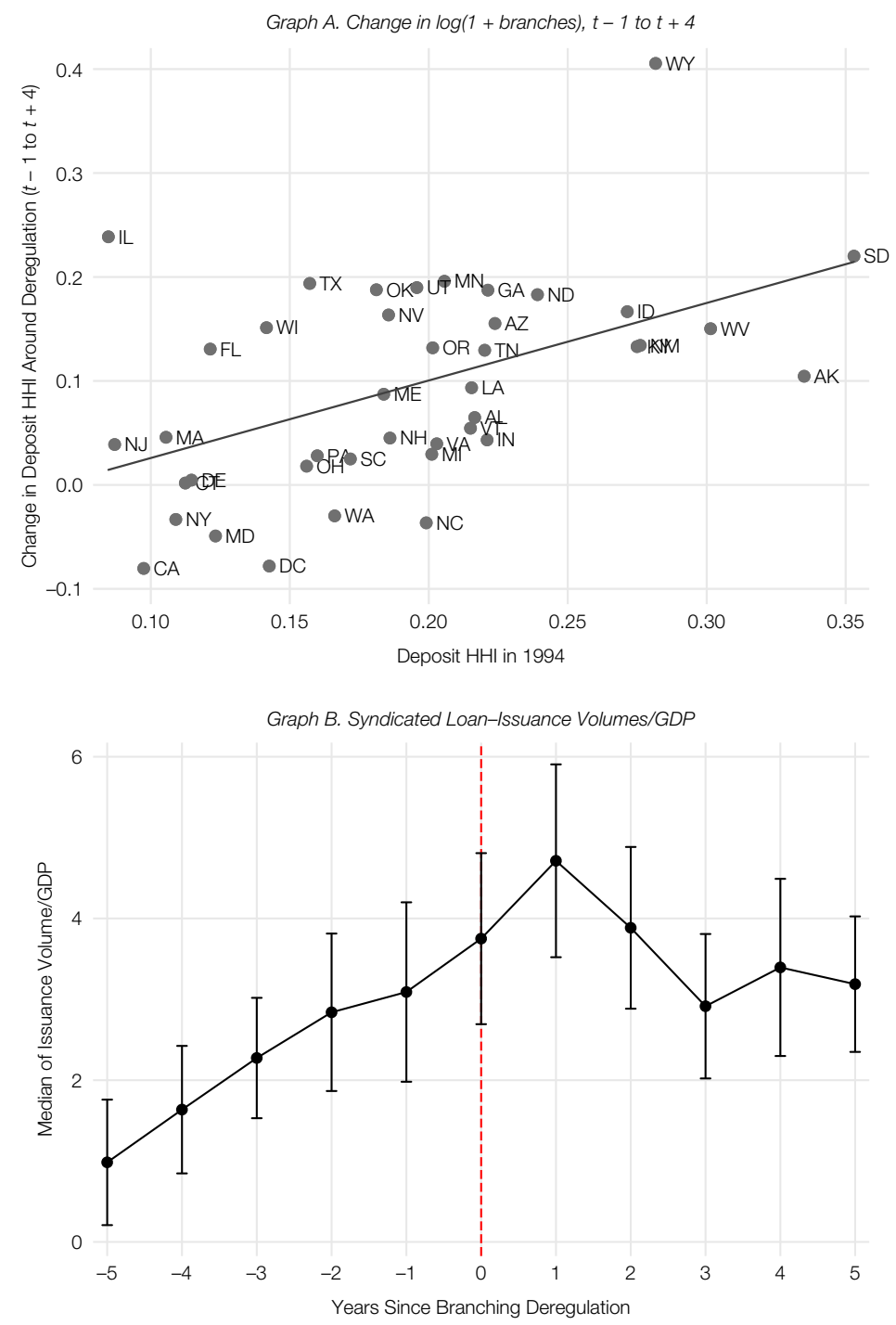

upward trend in total syndicated loan issuance. After IBBEA implementation, however, syndicated lending volume stalled and then decreased as a percentage of GDP. This is consistent with previous findings of Carey and Nini (2007) and Gadanecz (2004), who show that the U.S. syndicated loan market contracted after 1997, by which point most states had lifted at least some branching restrictions. 
We use these insights to sharpen the identification strategy first used by Rice and Strahan (2010) by conditioning the deregulation effect on a state's market concentration in 1994 (i.e., before states implemented the reform). ${ }^{27}$ As we discuss in Section IV.D, deregulation timing appears to be largely orthogonal to a state's pre-reform HHI. This gives us plausibly exogenous variation across states in the impact of interstate branching deregulation on the syndicated loan market.

More precisely, we run state-level panel regressions with a full set of state and year fixed effects of the following form:

$$
\begin{aligned}
\text { LOAN_VOL }_{s t}= & \beta_{1} \text { DEREG }_{s t}+\beta_{2} \text { DEREG }_{s t} \times \text { HHI_1994 }_{s} \\
& +\gamma \text { STATE_CONTROLS }_{s, t-1}+\alpha_{s}+\alpha_{t}+\varepsilon_{s t},
\end{aligned}
$$

where $\alpha_{s}$ and $\alpha_{t}$ are state and year dummies, respectively. Note that HHI_1994 by itself is absorbed by the state fixed effects. In some regressions, we also include the state-level controls real GSP per capita and house price growth. LOAN_VOL ${ }_{s t}$ is the ratio of either aggregate syndicated loan volume or bilateral loan volume, scaled by state GDP. ${ }^{28}$ Standard errors are clustered at the state level.

Table 5 plots the results of this exercise. In columns 1-3, we start by testing the impact of interstate branching on syndicated loan issuance, scaled over GSP. Consistent with the time-series pattern, the interaction term DEREG $\times$ HHI_1994 in column 2 has a negative estimated coefficient of -12.948 , which is highly statistically significant. This suggests that total yearly syndicated loan issuance decreased in states that were particularly affected by the IBBEA; this result is also robust to including the growth in house prices and real GDP per capita as control variables (column 3). To illustrate the implied magnitudes, consider the states

TABLE 5

Branching Deregulation and State-Level Loan Issuance

Table 5 reports results from state-level regressions of syndicated and bilateral loan issuance volumes (from DealScan) on a branching deregulation dummy, interacted with a state's market concentration in 1994. Loan volumes are scaled by state gross domestic product (GDP). State controls are real gross state product (GSP) growth and house price growth. All regressions include state and year fixed effects (FE). Robust standard errors (in parentheses) are clustered by state.

\begin{tabular}{|c|c|c|c|c|c|c|}
\hline & \multicolumn{3}{|c|}{ Syndicated Loan Volume } & \multicolumn{3}{|c|}{ Bilateral Loan Volume } \\
\hline & 1 & 2 & 3 & 4 & 5 & 6 \\
\hline DEREG & $\begin{array}{c}-0.524 \\
(0.652)\end{array}$ & $\begin{array}{l}1.988^{\star \star} \\
(0.979)\end{array}$ & $\begin{array}{c}1.735^{*} \\
(0.954)\end{array}$ & $\begin{array}{c}-0.027 \\
(0.072)\end{array}$ & $\begin{array}{c}-0.492^{\star \star} \\
(0.201)\end{array}$ & $\begin{array}{c}-0.479^{\star \star} \\
(0.217)\end{array}$ \\
\hline DEREG × HHI_1994 & & $\begin{array}{c}-12.948^{\star \star \star} \\
(3.464)\end{array}$ & $\begin{array}{c}-11.008^{\star \star \star} \\
(3.263)\end{array}$ & & $\begin{array}{l}2.400^{\star \star \star} \\
(0.857)\end{array}$ & $\begin{array}{c}2.366^{\star \star} \\
(0.924)\end{array}$ \\
\hline $\begin{array}{l}\text { State controls } \\
\text { State FE } \\
\text { Year FE }\end{array}$ & $\begin{array}{l}\text { Yes } \\
\text { Yes }\end{array}$ & $\begin{array}{l}\text { Yes } \\
\text { Yes }\end{array}$ & $\begin{array}{l}\text { Yes } \\
\text { Yes } \\
\text { Yes }\end{array}$ & $\begin{array}{l}\text { Yes } \\
\text { Yes }\end{array}$ & $\begin{array}{l}\text { Yes } \\
\text { Yes }\end{array}$ & $\begin{array}{l}\text { Yes } \\
\text { Yes } \\
\text { Yes }\end{array}$ \\
\hline $\begin{array}{l}\text { No. of obs. } \\
\text { Adj. } R^{2}\end{array}$ & $\begin{array}{l}1,071 \\
0.597\end{array}$ & $\begin{array}{l}1,071 \\
0.607\end{array}$ & $\begin{array}{l}1,020 \\
0.626\end{array}$ & $\begin{array}{l}1,071 \\
0.350\end{array}$ & $\begin{array}{l}1,071 \\
0.378\end{array}$ & $\begin{array}{l}1,020 \\
0.391\end{array}$ \\
\hline
\end{tabular}
${ }^{*},{ }^{* *}$, and ${ }^{* * *}$ indicate statistical significance at the $10 \%, 5 \%$, and $1 \%$ levels, respectively.

\footnotetext{
${ }^{27}$ Alaska is the only state that lifted any branching restriction contemporaneously with the passing of the IBBEA in 1994.

${ }^{28}$ Note that our results are not driven by an endogenous response of state GDP to deregulation; our results are qualitatively similar if we scale syndicated loan issuance over total C\&I loans from the FDIC.
} 
with the highest and lowest pre-reform concentration: South Dakota and Illinois, with a deposit HHI of 0.353 and 0.085 , respectively. Our estimates in column 2 imply that the more competitive Illinois saw an increase in the ratio of syndicated lending to GDP by $1.988-12.948 \times 0.085 \approx 0.891$. The syndicated loan ratio of South Dakota, in contrast, is estimated to drop sharply, by approximately 2.58 . Comparing the least and most concentrated states around deregulation thus implies a quantitatively large contraction in syndicated loan issuance/GDP of 1.48, approximately $53 \%$ of the pre-reform average ratio of 2.85 .

In columns 4-6 of Table 5, we find the opposite effect for bilateral loans. States that had little competition before the IBBEA saw disproportionate increases in direct lending post-deregulation. How does this lending increase compare to the drop in syndication? Again consider Illinois and South Dakota as examples at the opposite ends of market concentration prior to the reform. The estimates in column 5 imply that the ratio of bilateral loan issuance to GDP increased by $-0.492+2.400 \times 0.268 \approx 0.152$ in highly concentrated South Dakota compared with Illinois. Because the pre-reform bilateral lending ratio stood much lower at 0.253 , this suggests an increase in the credit supply of approximately $60 \%$.

These results are consistent with the result in Rice and Strahan (2010) that interstate branching eased credit constraints for small borrowers taking out direct loans. At the same time, our findings suggest a relatively small overall effect on credit volumes in percentage terms: The approximate $53 \%$ reduction in syndicated volumes was only marginally offset by the $60 \%$ increase in bilateral loans. However, these outcomes are subject to much stronger identifying assumptions than our loan- and bank-level results and should thus be interpreted with caution. They do, however, suggest that even at the aggregate state level, allowing banks to build branching networks led to a reshuffling of loan portfolios from syndicated to bilateral contracts.

Taken together with our evidence on spreads, the results suggest that allowing interstate branching led to a supply-driven substitution of syndicated for bilateral loan contracts.

\section{Threats to Identification}

\section{Loan-Level Correlates}

One concern with our loan-level results may be that our exposure variables EXP are not randomly assigned and thus capture deregulation effects unrelated to syndication. For example, banking-sector changes induced by the IBBEA could have a differential effect across different types of loans, independent of the substitution hypothesis we are testing. Because our results hold with a full set of borrower $\times$ year and bank $\times$ year fixed effects, any such effect would have to work through an interaction of state-level deregulation with correlates of the EXP measure.

Figure 5 investigates contract-level correlates of our exposure variables. More precisely, we plot standardized coefficients from regressing our loan-level control variables on the dummies for syndicated loans, commercial bank lenders, 


\section{FIGURE 5}

\section{Cross-Sectional Correlates of Exposure Variables}

Figure 5 plots the standardized estimated coefficients from regressing the loan characteristics on the left-hand side on the exposure variables (syndicated loans, commercial bank dummy, out-of-state bank dummy) after controlling for the vector of borrower fundamentals and year dummies. We also plot the $95 \%$ confidence intervals based on robust standard errors clustered by borrower.

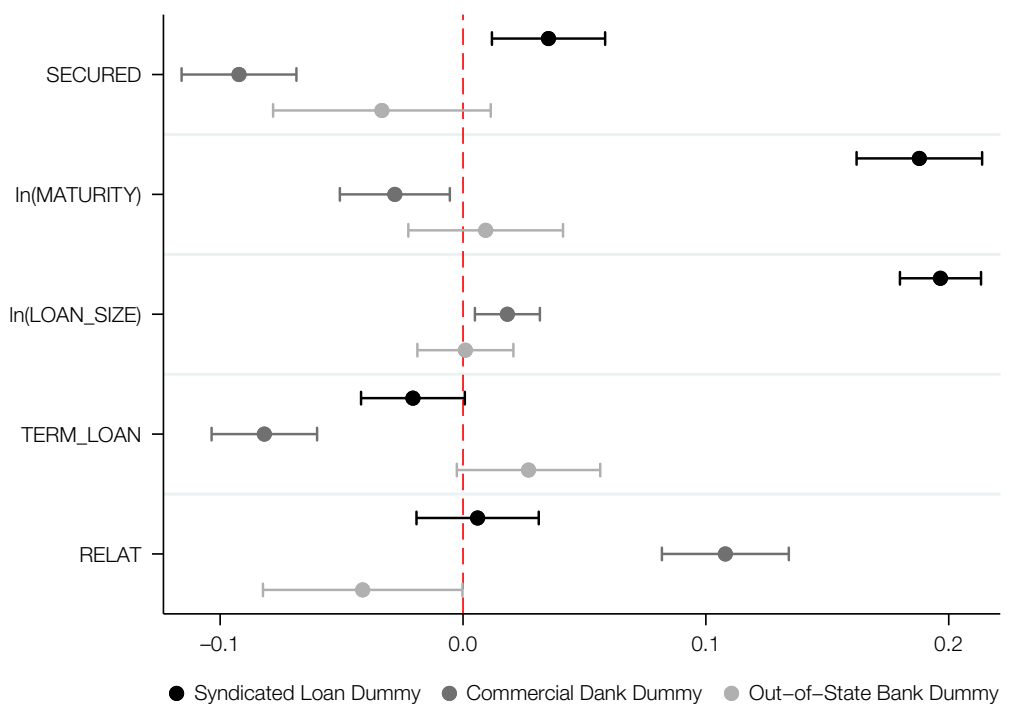

and out-of-state commercial banks. To make loans comparable, we control for borrower fundamentals and year dummies. ${ }^{29}$

As expected, the out-of-state bank dummy is not significantly correlated with any characteristic. The most obvious pattern that emerges is that syndicated loans are considerably larger than bilateral contracts and carry longer maturities, with a slightly higher likelihood of collateralization. Consistent with the existence of benefits to banking relationships, commercial banks do more repeat lending with lower collateralization; their contracts are also less likely to be term loans (i.e., more likely to be lines of credit). What matters is that across the different exposure measures, we find no systematic correlation with these other loan terms. Taken together with our results on preexisting trends in Section IV.A, it thus seems unlikely that unobservable loan characteristics are behind our findings.

In a further test, we access DealScan amendment files that record renegotiations resulting in interest spread changes for the same loan. This allows us to run regressions of changes in spreads for the same loan in a sample of amendment events with loan-facility fixed effects, holding other loan terms constant. ${ }^{30}$ We report the results in the Supplementary Material. Despite the small number of spread amendments, we find positive coefficients for all interacted coefficients

\footnotetext{
${ }^{29}$ The pattern is very similar without these control variables (available from the authors).

${ }^{30}$ Of course, this approach comes with another challenge: Although we "buy" the advantage of taking out differences between facilities at issuance, amendments in spreads may coincide with other contract changes. However, such within-contract amendments are of smaller magnitude than betweencontract differences, and we can control for these using a vector of the available variables.
} 
as before, although these sometimes lack statistical precision. Nevertheless, these results are further evidence that unobserved loan-level differences are unlikely to drive our findings.

\section{Endogenous Borrower Composition}

The most obvious explanation for observing higher spreads after deregulation is an increase in borrower risk. Because our loan-level estimations include a full set of borrower $\times$ year and bank $\times$ year fixed effects, differences in ex ante or realized firm-level risk cannot explain the increase. A change in risk may, however, play a role by interacting with our EXP variables.

We begin to address this by either including additional controls or altering the estimation sample. In the Supplementary Material, we show that our results also hold when including a control for numerical credit ratings. An increase in risk may also result from small firms expanding their market share due to better financing terms following deregulation. Yet, controlling for a borrower's market share in industry sales does not alter our estimates (column 4). In column 9 of Table A5 of the Supplementary Material, we also accommodate the concern that our findings may have something to do with institutional investor activity in syndicated loans by dropping all "Term Loan" and "Term Loan B" facilities. This yields a very similar point estimate of 0.052 (still highly significant).

It is also possible that safer borrowers opted out of the syndicated loan market after branching deregulation, which could affect the risk profile of "treated" loans. The intuition behind this concern is developed in models such as that of Bris and Welch (2005), where the "best firms" self-select into more concentrated credit contracts; bilateral loans would be the most extreme example. The figure in the Supplementary Material shows that this is not a valid concern in the aggregate: The share of loans issued by investment-grade borrowers was approximately stable around the IBBEA, and the share of rated borrowers slightly increased. This implies that, if anything, the quality of borrowers taking out syndicated loans increased with deregulation. More importantly, we find no differential selection of firms based on our EXP measures: Borrowers taking out "treated" loans were not riskier after deregulation compared to before (see Table A7 of the Supplementary Material). Taken together, these results allow us to conclude that changes in borrower risk are unlikely to drive our results.

\section{Changes in Credit Demand}

An alternative explanation for increased syndicated loan rates would be higher credit demand. Work by Jayaratne and Strahan (1996) and Huang (2008), among others, suggests that other episodes of U.S. banking deregulation have been associated with higher economic growth rates, which may increase the demand for credit. This concern is accommodated by our loan-level regressions with borrower $\times$ year fixed effects, which hold borrower fundamentals (including demand) constant. Further, in Section IV.C, we show that syndicated loan issuance contracted after branching deregulation. At the same time, we find that bilateral loan issuance grew post-IBBEA. The substitution between syndicated and bilateral loans thus cannot be explained by a higher overall demand for credit. 


\section{Endogenous Deregulation Timing}

Another potential threat to our identification strategy is that interstate branching deregulation may be endogenous to the size of the local syndicated loan market. Large lenders engaged in syndicated lending might have lobbied state legislators to delay deregulation in order to reap rents serving their client base. A decrease in syndicated loan activity could thus also reflect large banks lobbying less in these states due to lower future growth opportunities. Although it is not possible to test whether the deregulation timing is endogenous, we believe this is not a concern in our setting for two reasons.

First, existing evidence in Kroszner and Strahan (1999) and Rice and Strahan (2010) suggests it was smaller, not larger banks that lobbied for later interstate branching deregulation. Jayaratne and Strahan ((1996), (1998)) further show that states did not deregulate in anticipation of future growth prospects (which may have affected syndicated and bilateral loans differently).

Second, we find no correlation between deregulation timing and the size of the syndicated loan market or the degree of local market concentration before IBBEA implementation. The results from these tests can be found in tables in the Supplementary Material. Although only suggestive, they provide some evidence that our results are not driven by expectations correlated with deregulation.

\section{E. Exploring Borrower Heterogeneity}

Observing higher spreads after deregulation may initially be surprising, given the evidence in Rice and Strahan (2010) that IBBEA implementation decreased the cost of credit for small firms. In this section, we show that differences in sample composition are key to understanding why we find differential effects on syndicated and bilateral loans. We show that even in our sample, smaller, riskier, and more opaque borrowers saw a decrease in loan pricing, a result in accord with Rice and Strahan (2010). An intuitive interpretation is that lifting interstate branching restrictions considerably leveled the playing field in the U.S. credit market by decreasing the costs of screening and monitoring these types of borrowers (D'Acunto et al. (2017)). This is also consistent with the common finding in the literature on U.S. banking deregulation that small and opaque firms were the main beneficiaries (see, among others, Black and Strahan (2002), Kerr and Nanda (2009), Beck et al. (2010), and Chava et al. (2013)).

To test how differences across borrowers matter for squaring our results with previous findings, we run regressions with an interaction term as given by equation (2), where we condition the effect of the DEREG dummy on borrower characteristics. We define these characteristics in the year before a state implemented the IBBEA because borrower fundamentals may themselves become endogenous afterward. Specifically, we use borrower firm size (as measured by the log of total assets), asset tangibility, and numerical credit ratings as proxies for firms' ex ante opaqueness. The interaction with firm-level characteristics conveniently also enables us to include state $\times$ year fixed effects to absorb other potential state-level trends.

The results for borrower heterogeneity can be found in Table 6 . In column 1 , we introduce the interaction term with pre-reform firm size, as measured by the $\log$ of total assets. The interaction term DEREG $\times \ln ($ ASSETS $)$ is positive, 
TABLE 6

\section{Differential Effects Across Borrowers}

Table 6 reports the impact of interstate bank branch deregulation on the interest rates of loans in the syndicated market in the United States. The dependent variable is the lending rate spread from contracts included in the DealScan database. The explanatory variable is a dummy that equals 1 if a state lifts one or more branching restrictions for the first time, and 0 otherwise. See the text for included control variables. Robust standard errors (in parentheses) are clustered at the state level. ${ }^{*},{ }^{* *}$, and ${ }^{* \star *}$ indicate statistical significance at the $10 \%, 5 \%$, and $1 \%$ levels, respectively.

\begin{tabular}{|c|c|c|c|c|c|c|}
\hline & \multicolumn{6}{|c|}{ Interaction with Pre-Reform Borrower Characteristics } \\
\hline & \multicolumn{2}{|c|}{ In(ASSETS) } & \multicolumn{2}{|c|}{ PPE } & \multicolumn{2}{|c|}{ RATING } \\
\hline & 1 & 2 & 3 & 4 & 5 & 6 \\
\hline DEREG & $\begin{array}{c}-0.380^{\star * *} \\
(0.078)\end{array}$ & - & $\begin{array}{c}-0.054 \\
(0.043)\end{array}$ & - & $\begin{array}{c}0.218 \\
(0.138)\end{array}$ & - \\
\hline DEREG $\times$ interaction variable & $\begin{array}{l}0.063^{* * *} \\
(0.012)\end{array}$ & $\begin{array}{l}0.065^{\star \star \star} \\
(0.013)\end{array}$ & $\begin{array}{r}0.148^{*} \\
(0.078)\end{array}$ & $\begin{array}{c}0.145^{\star} \\
(0.084)\end{array}$ & $\begin{array}{c}-0.023^{\star *} \\
(0.012)\end{array}$ & $\begin{array}{c}-0.037^{\star \star \star} \\
(0.013)\end{array}$ \\
\hline $\begin{array}{l}\text { Loan controls } \\
\text { Borrower controls } \\
\text { Borrower FE } \\
\text { Year FE } \\
\text { State } \times \text { year FE }\end{array}$ & $\begin{array}{l}\text { Yes } \\
\text { Yes } \\
\text { Yes } \\
\text { Yes }\end{array}$ & $\begin{array}{l}\text { Yes } \\
\text { Yes } \\
\text { Yes } \\
- \\
\text { Yes }\end{array}$ & $\begin{array}{l}\text { Yes } \\
\text { Yes } \\
\text { Yes } \\
\text { Yes }\end{array}$ & $\begin{array}{l}\text { Yes } \\
\text { Yes } \\
\text { Yes } \\
- \\
\text { Yes }\end{array}$ & $\begin{array}{l}\text { Yes } \\
\text { Yes } \\
\text { Yes } \\
\text { Yes }\end{array}$ & $\begin{array}{l}\text { Yes } \\
\text { Yes } \\
\text { Yes } \\
- \\
\text { Yes }\end{array}$ \\
\hline $\begin{array}{l}\text { No. of obs. } \\
\text { Adj. } R^{2}\end{array}$ & $\begin{array}{l}4,407 \\
0.823\end{array}$ & $\begin{array}{l}4,323 \\
0.862\end{array}$ & $\begin{array}{l}4,403 \\
0.821\end{array}$ & $\begin{array}{l}4,319 \\
0.861\end{array}$ & $\begin{array}{l}1,861 \\
0.858\end{array}$ & $\begin{array}{l}1,754 \\
0.907\end{array}$ \\
\hline
\end{tabular}

but the DEREG dummy by itself now attracts a negative sign. The estimates suggest an important heterogeneity for the impact of IBBEA implementation within our sample: A firm in the 10th percentile of the size distribution saw a $12 \%$ decrease in spreads, whereas a firm in the 90 th percentile saw a $17 \%$ increase $^{31}$ Smaller firms thus benefited from interstate branching deregulation even within our sample, consistent with Rice and Strahan (2010), Acharya, Imbs, and Sturgess (2011), and Chava et al. (2013), among others. Although large firms still pay lower interest rates than small ones after deregulation, the differential between them narrows. Including a full set of state $\times$ year dummies in column 2 makes almost no difference to these estimates.

Other differences in borrower characteristics are also important mediators. Interest rate increases are concentrated in firms with higher pre-reform asset tangibility (as measured by fixed over total assets), with a negative (but imprecisely estimated) effect on firms with lower tangibility. Again, moving from the 10th to the 90 th percentile, this implies a range from a $4.2 \%$ decrease $(-0.054+0.148 \times$ $0.079 \approx-0.042)$ to a $4.7 \%$ increase $(-0.054+0.148 \times 0.684 \approx 0.047)$. Interest rates thus became relatively less responsive to fixed asset holdings after IBBEA implementation. To the extent that collateral is a tool to overcome asymmetric information between lenders and borrowers, this indicates reduced financial frictions. Another important margin for banking deregulation is firm risk (Neuhann and Saidi (2017)). The estimates in column 5 of Table 6 imply that firms with inferior credit ratings saw lower interest rates following branching deregulation. Going from an AAA rating (equal to 1 in our rating scale) to $\mathrm{BB}+$ (equal to 11 in our rating scale) implies a sizeable difference of $20.7 \log$ points in the effect

\footnotetext{
${ }^{31}$ We arrive at this estimate by calculating the total effect for a small firm (log assets of $\approx 4.082$ ) as $-0.380+0.063 \times 4.082 \approx-0.122$. Equivalently, for a large firm with total $(\log )$ assets of $\approx 8.760$, we calculate the total effect as $-0.380+0.063 \times 8.760 \approx 0.172$.
} 
of branching deregulation. For safe borrowers, spreads clearly increased; risky borrowers saw a decline in rates.

Overall, our results suggest that lifting interstate branching restrictions benefited opaque borrowers, which may be more expensive to screen and monitor. Although the average net effect on the spreads of syndicated loans in our sample was positive (albeit small), borrowers who are particularly subject to ex ante difficulties in tapping credit markets did indeed see lower rates. We find that the firms in our sample most similar to those examined by Rice and Strahan (2010) were the unconditional winners.

\section{F. Additional Robustness Checks}

We conduct a battery of further validity checks to assess the robustness of our main results. One worry may be that, despite the evidence of no preexisting trends in Section IV, our treatment variable may pick up secular state-level trends in the spreads of particular loans unrelated to deregulation. As an alternative test, we therefore conduct a placebo test by assuming that a state's IBBEA implementation occurred 7 years prior to the actual deregulation year, similar to Rice and Strahan (2010). The choice of 7 years is driven by the sample length: Our observations start in 1987, and the first state to allow interstate branching, Alaska, implemented the IBBEA in 1994. In the Supplementary Material, we show the results of running our baseline regressions over the time period of 1987-1994. All of the estimates for the placebo dummy are indistinguishable from 0 , providing yet more evidence that we are capturing a causal effect of branching deregulation.

Another concern may be that including borrower fixed effects leaves us with a "biased" sample of repeat borrowers. Because the syndicated loan market is characterized by repeated interactions between borrowers and lenders, however, we lose less than $5 \%$ of observations by requiring at least two loan contracts in the sample. We also show that our results hold between (instead of within) borrowers by exchanging borrower dummies with industry and state dummies in column 2 of Table A5 of the Supplementary Material.

The loan-level regressions we employ allow us to control for other contract determinants of spreads, such as the use of collateral. In order to alleviate concerns that these are jointly determined with interest rate spreads, we omit all loan controls in column 5 of Table A5 in the Supplementary Material. This makes no material difference in our point estimate. Additionally, there may be a concern that our panel regressions understate standard errors, despite the conservative clustering. We address this concern by collapsing the panel into two observations per firm, as suggested by Bertrand, Duflo, and Mullainathan (2004). We implement this by calculating the average interest rate before and after deregulation for each firm in the full sample (weighted by loan size) and regressing it on the post-deregulation dummy. The estimates in column 6 in Table A5 of the Supplementary Material show that this simple regression yields a point estimate of $\approx 0.085$ with a $t$-statistic of 6.32 , suggesting that our results are unlikely to be driven by suppressed standard errors.

As described previously, we establish our main results using the sample period of 1987-2007, excluding the Great Recession. In the Supplementary Material, we rerun all regressions in the full sample period available until 2012. 
The results in almost all specifications are now even more precisely estimated with largely unchanged coefficients, suggesting that the increases in interest rates on large loans we have documented throughout the article were not washed away by the financial crisis of 2007-2008. We also repeat our main estimation with the original Rice and Strahan (2010) index; column 7 in Table A5 of the Supplementary Material shows this has no substantial bearing on our result.

As a last exercise, we address the concern that large states are overrepresented in our sample and thus may drive the results. We run the baseline regression in equation (1) and exclude all individual states in turn. Figure A4 of the Supplementary Material plots the coefficient estimates of all of these regressions and compares them to the baseline result presented in Table 2. With the exception of a single outlier, excluding individual states makes little difference to the point estimate. Excluding Texas leads to a substantially higher coefficient (by almost $50 \%$ ). If anything, this suggests our sample composition actually understates the IBBEA's impact on syndicated loan spreads.

\section{Conclusion}

In this article, we show that the wave of state-level deregulation following the passage of the IBBEA had substantial effects on the syndicated loan market. We show that branching deregulation was associated with a substitution of syndicated for bilateral lending, accompanied by a narrower interest rate differential between (cheaper) syndicated and (more expensive) bilateral loan contracts. These findings are consistent with the interpretation that branching networks and syndication are partial substitutes for diversifying geographical credit risk.

The unique institutional setting of the IBBEA allows us to exploit crosssectional loan-level exposure to identify the causal effect of interstate branching. In particular, we show that the substitution effect was entirely driven by out-ofstate commercial banks, the only group legally affected by the reforms. Importantly, the higher lending competition expanded credit supply by other lenders, a result that aligns with previous evidence of Rice and Strahan (2010). We further find that these effects vary across borrowers: Small, risky firms with few tangible assets in particular stood to benefit from branching deregulation, even in our sample of relatively large companies. We add the nuance that this likely contributed to a more level playing field between large and small borrowers in the U.S. credit market.

Our findings suggest that abolishing geographic branching restrictions may have at least partially contributed to the declining share of the United States in the global syndicated loan market starting in the mid-1990s, as documented by Carey and Nini (2007) and Gadanecz (2004). This implies that the effects of financial reforms are far from uniform and may have a considerable differential impact on the pricing and allocation of credit. A promising area of future work is to study the consequences of other types of financial reforms and how other regulatory changes affected the syndicated loan market. 


\section{Appendix. Variable Definitions}

Loan characteristics (DealScan)

LOAN_SIZE: Facility amount in million USD.

SPREAD: Interest rate spread, usually over LIBOR, in basis points.

MATURITY: Loan maturity in months.

SECURED: Equal to 1 if loan is backed by collateral, and 0 otherwise.

RELAT: Equal to 1 if a firm received a bank from the same lead bank before, and 0 otherwise.

TERM_LOAN: Equal to 1 if loan is a term loan, and 0 otherwise.

PURPOSE: Vector of dummy variables for the different loan purposes.

SYN: Equal to 1 if the loan's distribution method is not "sole lender" (i.e., the loan is syndicated), and 0 otherwise.

Bank characteristics (DealScan/FDIC)

COMM_BANK: Equal to 1 if the creditor's SIC code starts with 602, and 0 otherwise.

OOS_BANK: Equal to 1 if a bank does not have branches in a borrower's state prior to deregulation, and 0 otherwise; defined only for commercial banks.

Firm characteristics (Compustat)

LEV: [Long-term debt $(d l t t)+$ debt in current liabilities $(d l c)] /$ total assets $(a t)$.

Q: $\quad$ [Common shares outstanding $(c s h o)$ price close - annual - calendar $($ prccc $)+$ debt in current liabilities $(d l c)+$ long-term debt $(d l t t)] /$ total assets $(a t)$.

ASSETS: Total assets (at).

ROA: Operating income before depreciation (oibdp)/total assets (at).

DEBT_CF_NEG: [Long-term debt $(d l t t)+$ debt in current liabilities $(d l c)$ ]/[operating income before depreciation (oibdp) + depreciation and amortization $(d p)$. Equal to 1 for negative values.

DEBT_CF_HIGH: [Long-term debt $(d l t t)+$ debt in current liabilities $(d l c)] /[$ operating income before depreciation (oibdp) + depreciation and amortization $(d p)$. Equal to 1 for the fourth quartile.

SALE_GR: Growth in sales/turnover (net) [(sale - sale $(t-1)) / \operatorname{sale}(t-1)]$.

RAT_DUM: Equal to 1 if a firm has any rating from S\&P, Fitch, Moody's, or Duffs \& Phelps.

RATING: Numerical credit rating, ranging from AAA to D.

PPE: [Property, plant and equipment (ppent)/total assets (at).

State characteristics

DEREG: Reversed deregulation index from Rice and Strahan (2010), where 0 is most restrictive and 4 is most liberalized.

DEREG_D: $\quad$ Set to 1 for the first year the reversed deregulation index is not 0 .

SYN_LOAN_VOL_GDP: Aggregate total volume of syndicated loans in DealScan, scaled over state GDP (GSP).

BIL_LOAN_VOL_GDP: Aggregate total volume of bilateral loans in DealScan, scaled over state GDP (GSP).

HHI_1994: County-level Herfindahl index of deposits in the pre-deregulation year, aggregated to the state level using county deposits as weights.

HP_GROWTH: Year-on-year growth in house prices. Source: Federal Housing Finance Agency.

GDP_GROWTH: Year-on-year growth in real GSP per capita. Source: BEA. 


\section{Supplementary Material}

Supplementary Material for this article is available at https://doi.org/10.1017/ S0022109019000607.

\section{References}

Acharya, V.; I. Hasan; and A. Saunders. "Should Banks Be Diversified? Evidence from Individual Bank Loan Portfolios.” Journal of Business, 79 (2006), 1355-1412.

Acharya, V. V.; J. Imbs; and J. Sturgess. "Finance and Efficiency: Do Bank Branching Regulations Matter?" Review of Finance, 15 (2011), 135-172.

Akhigbe, A., and A. M. Whyte. "Changes in Market Assessments of Bank Risk Following the RiegleNeal Act of 1994.” Journal of Banking and Finance, 27 (2003), 87-102.

Amiram, D.; W. Beaver; W. Landsman; and J. Zhao. "The Effects of Credit Default Swap Trading on Information Asymmetry in Syndicated Loans.” Journal of Financial Economics, 126 (2017), 364-382.

Amore, M. D.; C. Schneider; and A. Zaldokas. "Credit Supply and Corporate Innovation.” Journal of Financial Economics, 109 (2013), 835-855.

Angbazo, L. A.; J. Mei; and A. Saunders. "Credit Spreads in the Market for Highly Leveraged Transaction Loans." Journal of Banking and Finance, 22 (1998), 1249-1282.

Axelson, U.; T. Jenkinson; P. Strömberg; and M. S. Weisbach. "Borrow Cheap, Buy High? The Determinants of Leverage and Pricing in Buyouts." Journal of Finance, 68 (2013), 2223-2267.

Beck, T.; R. Levine; and A. Levkov. "Big Bad Banks? The Winners and Losers from Bank Deregulation in the United States." Journal of Finance, 65 (2010), 1637-1667.

Becker, B., and V. Ivashina. "Covenant-Light Contracts and Creditor Coordination.” Sveriges Riksbank Working Paper Series 325 (2016).

Berg, T.; A. Saunders; and S. Steffen. "The Total Cost of Corporate Borrowing in the Loan Market: Don't Ignore the Fees.” DEREG of Finance, 71 (2016), 1357-1392.

Berger, A. N.; R. S. Demsetz; and P. E. Strahan. "The Consolidation of the Financial Services Industry: Causes, Consequences, and Implications for the Future." Journal of Banking and Finance, 23 (1999), 135-194.

Berger, A. N.; A. Kashyap; J. Scalise; M. Gertler; and B. Friedman. "The Transformation of the US Banking Industry: What a Long, Strange Trip It's Been.” Brookings Papers on Economic Activity, 2 (1995), 55-218.

Berger, A. N., and G. Udell. Securitization, Risk, and the Liquidity Problem in Banking. Burr Ridge, IL: Irwin Publishers (1993).

Bertrand, M.; E. Duflo; and S. Mullainathan. "How Much Should We Trust Differences-in-Differences Estimates?" Quarterly Journal of Economics, 119 (2004), 249-275.

Bharath, S. T.; S. Dahiya; A. Saunders; and A. Srinivasan. "So What Do I Get? The Bank's View of Lending Relationships.” Journal of Financial Economics, 85 (2007), 368-419.

Bharath, S. T.; S. Dahiya; A. Saunders; and A. Srinivasan. "Lending Relationships and Loan Contract Terms." Review of Financial Studies, 24 (2011), 1141-1203.

Black, S. E., and P. E. Strahan. "Entrepreneurship and Bank Credit Availability." Journal of Finance, 57 (2002), 2807-2833.

Bolton, P., and D. S. Scharfstein. "Optimal Debt Structure and the Number of Creditors." Journal of Political Economy, 104 (1996), 1-25.

Boot, A. W. A., and A. V. Thakor. "Can Relationship Banking Survive Competition?" Journal of Finance, 55 (2000), 679-713.

Boyd, J. H., and E. C. Prescott. "Financial Intermediary-Coalitions." Journal of Economic Theory, 38 (1986), 211-232.

Bris, A., and I. Welch. "The Optimal Concentration of Creditors.” Journal of Finance, 60 (2005), 2193-2212.

Bris, A.; I. Welch; and N. Zhu. "The Costs of Bankruptcy: Chapter 7 Liquidation versus Chapter 11 Reorganization.” Journal of Finance, 61 (2006), 1253-1303.

Cai, J.; F. Eidam; A. Saunders; and S. Steffen. "Syndication, Interconnectedness, and Systemic Risk." Journal of Financial Stability, 34 (2018), 105-120.

Calomiris, C. W. U.S. Bank Deregulation in Historical Perspective. Cambridge, UK: Cambridge University Press (2000).

Calomiris, C. W. U.S. Bank Deregulation in Historical Perspective. Cambridge, UK: Cambridge University Press (2006). 
Carey, M., and G. Nini. "Is the Corporate Loan Market Globally Integrated? A Pricing Puzzle." Journal of Finance, 62 (2007), 2969-3007.

Cetorelli, N., and P. E. Strahan. "Finance as a Barrier to Entry: Bank Competition and Industry Structure in Local U.S. Markets.” Journal of Finance, 61 (2006), 437-461.

Chava, S.; A. Oettl; A. Subramanian; and K. V. Subramanian. "Banking Deregulation and Innovation." Journal of Financial Economics, 109 (2013), 759-774.

Chava, S., and M. R. Roberts. "How Does Financing Impact Investment? The Role of Debt Covenants." Journal of Finance, 63 (2008), 2085-2121.

Chodorow-Reich, G. "The Employment Effects of Credit Market Disruptions: Firm-Level Evidence from the 2008-9 Financial Crisis." Quarterly Journal of Economics, 129 (2014), 1-59.

D’Acunto, F.; R. Liu; C. Pflueger; and M. Weber. "Flexible Prices and Leverage." Journal of Financial Economics, 129 (2018), 46-68.

Dahiya, S.; A. Saunders; and A. Srinivasan. "Financial Distress and Bank Lending Relationships." Journal of Finance, 58 (2003), 375-399.

Dass, N., and M. Massa. "The Impact of a Strong Bank-Firm Relationship on the Borrowing Firm." Review of Financial Studies, 24 (2011), 1204-1260.

De Haas, R., and N. Van Horen. "International Shock Transmission after the Lehman Brothers Collapse: Evidence from Syndicated Lending.” American Economic Review, 102 (2012), 231-237.

Degryse, H., and S. Ongena. "Distance, Lending Relationships, and Competition." Journal of Finance, 60 (2005), 231-266.

Demsetz, R. S. "Bank Loan Sales: A New Look at the Motivations for Secondary Market Activity." Journal of Financial Research, 23 (2000), 197-222.

Demsetz, R. S., and P. E. Strahan. "Diversification, Size, and Risk at Bank Holding Companies." Journal of Money, Credit and Banking, 29 (1997), 300-313.

Deng, S., and E. Elyasiani. "Geographic Diversification, Bank Holding Company Value, and Risk." Journal of Money, Credit and Banking, 40 (2008), 1217-1238.

Dennis, S. A., and D. J. Mullineaux. "Syndicated Loans." Journal of Financial Intermediation, 9 (2000), 404-426.

Diamond, D. W. "Financial Intermediation and Delegated Monitoring." Review of Economic Studies, 51 (1984), 393.

Dougal, C.; J. Engelberg; C. A. Parsons; and E. D. Van Wesep. "Anchoring on Credit Spreads." Journal of Finance, 70 (2015), 1039-1080.

Falato, A., and N. Liang. "Do Creditor Rights Increase Employment Risk? Evidence from Loan Covenants." Journal of Finance, 71 (2016), 2545-2590.

Favara, G., and J. Imbs. "Credit Supply and the Price of Housing." American Economic Review, 105 (2015), 958-992.

Ferreira, M. A., and P. Matos. "Universal Banks and Corporate Control: Evidence from the Global Syndicated Loan Market.” Review of Financial Studies, 25 (2012), 2703-2744.

Gadanecz, B. "The Syndicated Loan Market: Structure, Development and Implications." BIS Quarterly Review, (2004), 75-89.

Gaspar, J.; M. Massimo; and P. Matos. "Favoritism in Mutual Fund Families? Evidence on Strategic Cross-Fund Subsidization.” Journal of Finance, 61 (2006), 73-104.

Gertner, R., and D. Scharfstein. "A Theory of Workouts and the Effects of Reorganization Law." Journal of Finance, 46 (1991), 1189-1222.

Goetz, M. R.; L. Laeven; and R. Levine. "Identifying the Valuation Effects and Agency Costs of Corporate Diversification: Evidence from the Geographic Diversification of U.S. Banks." Review of Financial Studies, 26 (2013), 1787-1823.

Goetz, M. R.; L. Laeven; and R. Levine. "Does the Geographic Expansion of Banks Reduce Risk?" Journal of Financial Economics, 120 (2016), 346-362.

Gompers, P.; J. Lerner; and D. Scharfstein. "Entrepreneurial Spawning: Public Corporations and the Genesis of New Ventures, 1986 to 1999.” Journal of Finance, 60 (2005), 577-614.

Gopalan, R.; V. Nanda; and V. Yerramilli. "Does Poor Performance Damage the Reputation of Financial Intermediaries? Evidence from the Loan Syndication Market.” Journal of Finance, 66 (2011), 2083-2120.

Gopalan, R.; G. F. Udell; and V. Yerramilli. "Why Do Firms Form New Banking Relationships?" Journal of Financial and Quantitative Analysis, 46 (2011), 1335-1365.

Gorton, G. B., and G. G. Pennacchi. "Banks and Loan Sales Marketing Nonmarketable Assets." Journal of Monetary Economics, 35 (1995), 389-411.

Hart, O., and J. Moore. "Debt and Seniority: An Analysis of the Role of Hard Claims in Constraining Management." American Economic Review, 85 (1995), 567-585.

Hauswald, R., and R. Marquez. "Competition and Strategic Information Acquisition in Credit Markets.” Review of Financial Studies, 19 (2006), 967-1000. 
Hollander, S., and A. Verriest. "Bridging the Gap: The Design of Bank Loan Contracts and Distance." Journal of Financial Economics, 119 (2016), 399-419.

Holmstrom, B., and J. Tirole. "Financial Intermediation, Loanable Funds, and the Real Sector." Quarterly Journal of Economics, 112 (1997), 663-691.

Hombert, J., and A. Matray. "The Real Effects of Lending Relationships on Innovative Firms and Inventor Mobility.” Review of Financial Studies, 30 (2016), 2413-2445.

Huang, R. R. "Evaluating the Real Effect of Bank Branching Deregulation: Comparing Contiguous Counties across US State Borders.” Journal of Financial Economics, 87 (2008), 678-705.

Hughes, J. P.; W. Lang; L. J. Mester; and C.-G. Moon. "Efficient Banking under Interstate Branching." Journal of Money, Credit and Banking, 28 (1996), 1045-1071.

Ivashina, V. "Structure and Pricing of Syndicated Loans." Technical Report, Federal Reserve Bank (2005)

Ivashina, V. “Asymmetric Information Effects on Loan Spreads.” Journal of Financial Economics, 92 (2009), 300-319.

Ivashina, V., and D. Scharfstein. "Loan Syndication and Credit Cycles." American Economic Review, 100 (2010), 57-61.

Ivashina, V.; D. S. Scharfstein; and J. C. Stein. "Dollar Funding and the Lending Behavior of Global Banks." Quarterly Journal of Economics, 130 (2015), 1241-1281.

Jayaratne, J., and P. E. Strahan. "The Finance-Growth Nexus: Evidence from Bank Branch Deregulation." Quarterly Journal of Economics, 111 (1996), 639-670.

Jayaratne, J., and P. E. Strahan. "Entry Restrictions, Industry Evolution, and Dynamic Efficiency: Evidence from Commercial Banking." Journal of Law and Economics, 41 (1998), 239-274.

Jiang, L.; R. Levine; and C. Lin. “Does Competition Affect Bank Risk?” Working Paper 23080, National Bureau of Economic Research, available at https://www.nber.org/papers/w23080 (2017).

Jiménez, G.; S. Ongena; J.-L. Peydró; and J. Saurina. "Hazardous Times for Monetary Policy: What Do Twenty-Three Million Bank Loans Say about the Effects of Monetary Policy on Credit RiskTaking?" Econometrica, 82 (2014), 463-505.

Johnson, C. A., and T. Rice. "Assessing a Decade of Interstate Bank Branching." Washington and Lee Law Review, 65 (2008), 73.

Kalemli-Ozcan, S.; H. Kamil; and C. Villegas-Sanchez. "What Hinders Investment in the Aftermath of Financial Crises: Insolvent Firms or Illiquid Banks?" Review of Economics and Statistics, 98 (2016), 756-769.

Kerr, W. R., and R. Nanda. "Democratizing Entry: Banking Deregulations, Financing Constraints, and Entrepreneurship.” Journal of Financial Economics, 94 (2009), 124-149.

Khwaja, A. I., and A. Mian. "Tracing the Impact of Bank Liquidity Shocks: Evidence from an Emerging Market.” American Economic Review, 98 (2008), 1413-1442.

Koetter, M.; J. W. Kolari; and L. Spierdijk. "Enjoying the Quiet Life under Deregulation? Evidence from Adjusted Lerner Indices for U.S. Banks.” Review of Economics and Statistics, 94 (2012), $462-480$.

Kroszner, R. S., and P. E. Strahan. "What Drives Deregulation? Economics and Politics of the Relaxation of Bank Branching Restrictions.” Quarterly Journal of Economics, 114 (1999), 1437-1467.

Kroszner, R. S., and P. E. Strahan. Regulation and Deregulation of the U.S. Banking Industry: Causes, Consequences and Implications for the Future. Chicago, IL: University of Chicago Press (2014).

Lee, S. J.; L. Q. Liu; and V. Stebunovs. "Risk Taking and Interest Rates: Evidence from Decades in the Global Syndicated Loan Market. International Finance Discussion Papers 1188, National Bureau of Economic Research (2017).

Lepetit, L.; E. Nys; P. Rous; and A. Tarazi. "The Expansion of Services in European Banking: Implications for Loan Pricing and Interest Margins." Journal of Banking and Finance, 32 (2008), 2325-2335.

Li, Y.; R. Lu; and A. Srinivasan. "Relationship Bank Behavior During Borrower Distress.” Journal of Financial and Quantitative Analysis, 54 (2019), 1231-1262.

Lim, J.; B. A. Minton; and M. S. Weisbach. "Syndicated Loan Spreads and the Composition of the Syndicate.” Journal of Financial Economics, 111 (2014), 45-69.

Lin, C.; Y. Ma; P. Malatesta; and Y. Xuan. "Corporate Ownership Structure and Bank Loan Syndicate Structure.” Journal of Financial Economics, 104 (2012), 1-22.

Muermann, A.; T. Rauter; and C. Scheuch. "Fishing with Pearls: The Value of Lending Relationships with Prestigious Firms." Technical Report, available at https://ssrn.com/abstract=2703343 (2017).

Müller, K. "Busy Bankruptcy Courts and the Cost of Credit." Working Paper, available at https://ssrn .com/abstract=3088676 (2019).

Nandy, D. K., and P. Shao. "Institutional Investment in Syndicated Loans." Unpublished Working Paper, Brandeis University (2010). 
Neuhann, D., and F. Saidi. "Do Universal Banks Finance Riskier but More Productive Firms?” Journal of Financial Economics, 128 (2018), 66-85.

Nini, G.; D. C. Smith; and A. Sufi. "Creditor Control Rights and Firm Investment Policy." Journal of Financial Economics, 92 (2009), 400-420.

Pennacchi, G. G. "Loan Sales and the Cost of Bank Capital.” Journal of Finance, 43 (1988), 375-396.

Petersen, M. A. "Estimating Standard Errors in Finance Panel Data Sets: Comparing Approaches." Review of Financial Studies, 22 (2009), 435-480.

Petersen, M. A., and R. G. Rajan. "Does Distance Still Matter? The Information Revolution in Small Business Lending." Journal of Finance, 57 (2002), 2533-2570.

Preece, D., and D. J. Mullineaux. "Monitoring, Loan Renegotiability, and Firm Value: The Role of Lending Syndicates." Journal of Banking and Finance, 20 (1996), 577-593.

Rice, T., and P. E. Strahan. "Does Credit Competition Affect Small-Firm Finance?" Journal of Finance, 65 (2010), 861-889.

Roberts, M. R., and A. Sufi. "Control Rights and Capital Structure: An Empirical Investigation." Journal of Finance, 64 (2009), 1657-1695.

Ross, D. G. “The 'Dominant Bank Effect': How High Lender Reputation Affects the Information Content and Terms of Bank Loans." Review of Financial Studies, 23 (2010), 2730-2756.

Saidi, F., and D. Neuhann. "Do Universal Banks Finance Riskier But More Productive Firms?” Journal of Financial Economics, 128 (2018), 66-85.

Schenone, C. "Lending Relationships and Information Rents: Do Banks Exploit Their Information Advantages?" Review of Financial Studies, 23 (2010), 1149.

Simons, K. "Why Do Banks Syndicate Loans?” New England Economic Review (1993), 45-52.

Stiroh, K. J., and P. E. Strahan. "Competitive Dynamics of Deregulation: Evidence from U.S. Banking." Journal of Money, Credit, and Banking, 35 (2003), 801-828.

Sufi, A. "Information Asymmetry and Financing Arrangements: Evidence from Syndicated Loans." Journal of Finance, 62 (2007), 629-668. 